\title{
Anatolia's eternal destiny was sealed: Seljuks of Rum in the Turkish national(ist) imagination from the late Ottoman Empire to the Republican era
}

Doğan Gürpınar

\section{(2) OpenEdition \\ Journals}

Édition électronique

URL : https://journals.openedition.org/ejts/4547

DOI : 10.4000/ejts.4547

ISSN : 1773-0546

Éditeur

EJTS

Référence électronique

Doğan Gürpınar, «Anatolia's eternal destiny was sealed: Seljuks of Rum in the Turkish national(ist) imagination from the late Ottoman Empire to the Republican era », European Journal of Turkish Studies [En ligne], Liste complète, mis en ligne le 02 mai 2012, consulté le 15 février 2023. URL : http:// journals.openedition.org/ejts/4547 ; DOI : https://doi.org/10.4000/ejts.4547

Ce document a été généré automatiquement le 29 septembre 2020.

Creative Commons - Attribution - Pas d'Utilisation Commerciale - Pas de Modification 4.0 International - CC BY-NC-ND 4.0

https://creativecommons.org/licenses/by-nc-nd/4.0/ 


\title{
Anatolia's eternal destiny was sealed: Seljuks of Rum in the Turkish national(ist) imagination from the late Ottoman Empire to the Republican era
}

\author{
Doğan Gürpınar
}

It has become a truism that nations were invented in Europe with the onset of modernity through nation-building processes which involved "element of artifact, invention and social engineering" (Hobsbawm 1990: 10). Whereas for Ernest Gellner reasons for this "invention" lay in the growth of markets and for Benedict Anderson in print-capitalism which had emerged in the "explosive interaction between capitalism [and] technology" (Anderson 1983: 45), Miroslav Hroch argued that nationalism was an artifact and fantasy of the intellectuals, especially in Eastern Europe, where it emerged more as an intellectual curiosity than as a political imperative before nation-building efforts reached "C phase" (given that Eastern European societies were "stateless nations") (Hroch 1985). Likewise, Anne-Marie Thiesse maintained that, contrary to their claims to authenticity and uniqueness, the European trajectories of all nationbuilding processes throughout the European continent replicated each other. For her, the checklist of nationalization included "founding fathers, a historical narrative that provides a sense of continuity across the vicissitudes of history itself, a series of heroes, a language, cultural and historical monuments, sites of shared memory, a typical landscape, a folklore, not to mention a variety of more picturesque features, such as costumes, gastronomy and an emblematic animal or beast" (Thiesse 2007: 16-17; Thiesse 2001; Smith 2009: 35-40, 90-103; Suny, Kennedy 2001). That is, they all claim to be the natural and inevitable political manifestations of a historical essence and to embody a certain historical imagination. Nevertheless, for others, it would be misleading to see these motifs and historical ascriptions as merely instrumental. The variations of national references found in the depths of history all contributed to the 
molding of the "national panorama". Criticizing the "modernists" who are "wont to describe this one-way relationship between past and present" (Smith 2009), Anthony Smith argues that the symbolic reservoir such as the "myths, memories, traditions, and symbols of ethnic heritages" (Smith 1999: 9) which the nationalists utilized also had an impact on the modalities of the "national panorama". Hence, the "historical backgrounds" enjoy contingent power to shape "today", not via path dependencies but via their contributions to the molding of historical and national imaginations.

2 This article will examine the employment of some historical references, namely the Seljuks of Rum and the Battle of Manzikert, one of the most celebrated episodes of Turkic history that heralded the Turkification of Anatolia, in the construction of alternative and conflicting national imaginations. It will discuss the historiography of the Seljuks of Rum as it emerged in the early $20^{\text {th }}$ century and developed in the republican era as a national icon and show how the Seljuk polity was juxtaposed with contesting national imaginations, thus providing an arsenal of arguments for alternative claims to Turkic history. There is no one single trajectory of Turkish nationalism, but contesting and even contradicting visions of national identity and awareness which have been projected onto the imagined pasts. Thus, a critical engagement with the (inevitably nationalist) Turkish historiography reveals the modifications, transformations and continuities of Turkish nationalism from the late Ottoman Empire, when nationalism was blended with imperial and confessional identities and loyalties, to the staunchly secular and radically modern republican Kemalist nationalism.

3 The article will observe the development of a national-historical imagination in its making. Rather than discuss the development of the historiography of the Seljuks of Rum as an academic field, it will scrutinize what meanings and symbolisms were attributed to the Seljuks of Rum at different historical moments by actors motivated by different political and ideological convictions. It will discuss the representations of certain historical conjectures germane to the agendas of the late Ottoman-Turkish intelligentsia and attest the contours and premises of the late Ottoman-Turkish historiographical visions. By revealing the diverse and sometimes contradictory premises and agendas of Turkish nationalist discourses, the article will also demonstrate the complicated and multilayered nature of the modern Turkish national imaginations as they were revealed in different historical imaginations. Demonstrating the continuities and discontinuities from the late-Ottoman historical imaginations to the Kemalist historical visions allow me to elaborate on the Smithian claim that historical backgrounds have a contingent relationship to the present.

\section{Seljuks as the Precursors of the Ottomans}

4 Anatolia between the Turkish invasions and the Ottoman era was almost a terra incognita for the historians at the beginning of the $20^{\text {th }}$ century. The imposing presence of the Ottomans through six centuries all but obliterated Anatolia's earlier history and rendered it irrelevant and unattractive in the eyes of scholars. This did not stem from the deliberate Ottoman neglect of the Seljuks, as might be expected. The Ottomans themselves did not omit the Seljuks of Rum. On the contrary, the Ottoman tradition (as conveyed extensively in Neşri, (Neşri 1949: 55-71) Ibn-i Kemal, (Ibn-i Kemal 1970:26) Aşıkpaşazade, (Aşıkpaşazade 2003: 321-323) and in other Ottoman chronicles (Oruç Beğ 
2007: 3-10) based the legitimacy of the the Ottoman dynastic leadership on the claim that it succeeded the sultans in Konya (and the earlier Turkic dynasties). This halo of legitimacy was supposedly transmitted to the Ottomans thanks to the loyalty and deference shown by Ertuğrul Gazi and Osman Gazi to the Seljuks and the reciprocal support and encouragement the Seljuks gave to the minor Ottoman frontier principality. Although this perception was most overt in Neşri's Cihan-nüma, in which long passages were devoted to the exploits of the pre-Ottoman Turkic polities establishing a linear trajectory from the pre-Islamic Turkic polities to the Ottomans via the Seljuks and the Seljuks of Rum, (Neşri 1949: 2-69) it was not unique to Neşri. The narrative was present in the other Ottoman accounts to varying degrees. A forged imperial edict from the Seljuk sultan Alaeddin to Osman Gazi was included in Feridun Bey's $16^{\text {th }}$ century Münşeat-ül Salatin in order to demonstrate the transmission of legitimacy from the Seljuks to the Ottomans (Danişmend 1971:3; Yinanç 1924: 216-226) alongside another forged Seljuk decree which bestowed the lands in the frontier areas to Osman Gazi (Danişmend 1971: 4). This mode of legitimacy was apparently imbued with Turkic overtones (as well as Islamic connotations), arguably a derivation of the Turkic political culture in which one khan could legitimately overwhelm the steppes and subdue others. This tradition and its Turkic overtones was modified and further reinvigorated in the $19^{\text {th }}$ century with the emergence of a modern national consciousness among the Ottoman intelligentsia.

5 In Ahmed Cevdet Pasha's (1822-1895) History, the monumental study that reconciles the reforming Ottoman Empire of the $19^{\text {th }}$ century with its Ottoman and Islamic heritage, ${ }^{1}$ the link between the Ottoman principality and the Iconium sultans of Rum was established as follows: "Although the Iconium sultans of Rum had been one of the strongest polities in the abode of Islam, they were weakened by the Tartars. They even had to pay tribute to the Tartars. After years of disorder and difficulties, this polity waned and was subsequently demolished in the year 699 (A.H.) [1299 A.D.] At that time, thanks to God, the dark beginning's happy conclusion and nightmarish dreams' optimistic interpretation, the Ottomans rose and gave light to all the Islamic lands and the neighboring lands" (Ahmed Cevdet Paşa 1309: v. I, 29). Ahmed Cevdet Pasha reiterated the Ottoman narrative and maintained that the drum and the tail, the two Turkic symbols of sovereignty and authority, had been dispatched to the young Osman from the sultan in Konya after his victory against the Greeks, epitomizing the transfer of the mandate to govern the Muslims and Turks from the Konya sultanate to the young Osman.

6 Ahmed Vefik Pasha (1823-1891), another Tanzimat statesman and polymath, also contrasted the deference of Osman Bey with the opportunism of the other Turcoman warlords by underlining that after Osman Bey conquered castles in the frontier areas, the drum and the tail were dispatched from Konya (Ahmed Vefik Paşa 1286: 1-2) at a time when disloyal Seljuk governors were striving for independence (dava-yl istiklale düşüyorlar) (Ahmed Vefik Paşa 1286: 3). Ahmed Rasim (1864-1932), in his popular history of the Ottoman Empire, not only highlighted the loyalty of Osman Gazi to the Seljuk sultans at a time when Tartars were attacking the Seljuks and disloyal governors were betraying them in an attempt to benefit from the chaos, but also conveyed an account (taken from Neşri) in which Ertuğrul Bey heroically saved defeated Seljuk soldiers from the Tartar menace, enhancing the confidence of the Seljuk sultan in Ertuğrul Bey (Ahmed Rasim 1326-1328: 1-8). In a similar vein, Ali Seydi (1870-1933), the 
author of numerous Ottoman school textbooks, regarded the Ottoman principality as the "heir and successor" [varis ve halefi] to the Seljuks of Rum and noted that the Ottoman principality proclaimed its independence only after the dissolution of the Seljuk polity (Ali Seydi 1329: 12). All these late Ottoman intellectuals and historians reiterated the traditional Ottoman narrative in articulating that the frontier territories were bestowed upon the house of Osman by the Seljuks of Rum to fight the Greeks, thus establishing a lineage of legitimacy $[k u t]$ transferred from the Seljuks to the Ottomans.

Although this tradition was not dismissive of the pre-Ottoman Turkic and Islamic heritage, it employed the Turkic heritage primarily in order to legitimize the rule of the Ottoman dynasty. As David Kushner has demonstrated, there was already a growing interest in both Islamic and pre-Islamic Turkic history during the Hamidian era, an interest apparent in the daily newspaper Ikdam, which endorsed the motto Türk Gazetesidir (A Turkish daily) (Kushner 1977) ${ }^{2}$ As an example of the swelling interest in the pre-Ottoman Turks and the positioning of the Ottoman Empire within this glorious past, the prolific writer Ahmed Midhat Efendi (1844-1912) pointed out in his 1887 world history that "the millions of Turks whom Seljuks brought and settled in these areas mixed with the Ottomans and increased their numbers. If they had not existed, and the Ottoman state had to be founded in the midst of Greeks, Kurds, Arabs and Georgians, these nomads [the Ottomans], only four hundred in number, would not have been able to assert themselves" (Ahmed Midhat Efendi, 1303: v. I, 135; quoted in Kushner 1977: 35).

8 The historical Turkish identity was explored in the late $19^{\text {th }}$ century, and its scope was so much expanded that as early as 1869 the Polish convert Mustafa Celaleddin Pasha declared that the Etruscans were Turkish (Copeaux 1997: 17). Diverse figures such as the eccentric Young Ottoman Ali Suavi (1838-1878), the polymath Ahmed Vefik Pasha (1823-1891), and the military commander Süleyman Pasha (1838-1892) showed a profound interest in pre-Islamic Turkic history. The modes of dynastic legitimacy and the functions and meanings of dynastic governance were also changing. Abdülhamid "invented" new modes of legitimization by popularizing and nationalizing the dynastic legitimacy (Deringil 1998). Nevertheless, it was the impact of 1908 Revolution that caused these undercurrents to proliferate in the public sphere and to be endorsed by a broader intellectual public. The earlier Turkists ${ }^{3}$ of the Hamidian imperial elite seemed outmoded in light of the visions of Ottoman imperialism among the radical Young Turks. For them, the dynastic legitimacy had to be established in accordance with national aspirations and had to be based on national modes of legitimacy. The dynasty should serve the nation, not the other way around. The changing parameters of imperial legitimacy prompted renewed interest in the Seljuks, who were no more perceived as merely a prelude to Ottoman history, but as a pivotal and indispensable chain in Turkic history culminating in the Ottoman Empire. In 1914, Necib Asım and Mehmed Arif, in the first volume of Osmanl Tarihi [History of the Ottoman Empire] written for the collective project of the Ottoman Historical Association, epitomized the shift in the historical meaning of the Ottoman polity at its best (Necib Asım, Mehmed Arif 1340). Almost the entire volume was devoted to pre-Ottoman Turkic history, beginning with the numerous pre-Islamic and Islamic Turkic polities in Central Asia and ending with an extensive discussion of the Seljuks of Rum. By thus placing the Seljuks within the broader Turkic history, the Ottoman Empire began to be treated not 
as the natural and preordained end of this trajectory, but as the contemporary Turkic polity, merely another chain in a sequence.

The impact of the 1908 Revolution was profound not only with regard to the structure of politics, but also with regard to the course of Ottoman historiography. The 1908 Revolution considerably liberalized the conditions of history writing, and the intellectual and cultural environment enabled a new and vibrant historiography to flourish. In the liberal and open atmosphere of the second constitutional period the Tarih-i Osmani Encümeni [Ottoman Historical Association] was founded by prominent intellectuals of the Hamidian era, including the early Turkist Necib Asım (Akbayrak 2009). New intellectual milieus imbued with new historical visions emerged around nationalist journals such as Türk Yurdu and Halka Doğru, in which numerous stimulating articles were published on Turkish history, archeology, literature, and sociology from the early 1910s onward (Berktay 1983a: 2459). In the Milli Tetebbüler Mecmuası [National Journal of Research], Turkist historians pursued new historical curiosities, first and foremost pre-Ottoman Turkic history. Dynastic historiography centered upon the Ottomans was transformed. In 1913 Yusuf Akçura ferociously criticized Tarih-i Osmani Encümeni by arguing that the association only drew attention to great men, sultans, pashas, and beys without providing any analytical framework, and that it ignored socio-economic backgrounds (Georgeon 1996: 72-76). Turkist intellectuals such as Akçura focused on grander themes in history and dismissed political history as detail an Annales paradigm embedded within Turkish nationalism.

The burgeoning interest in the Seljuks of Rum in the 1910s was a composite result of social, economic, and political developments of the early $20^{\text {th }}$ century such as the decentralization of historiography and the loosening of the grip of the Ottomans over the historical national imagination. Local sources only began to be deciphered in the late $19^{\text {th }}$ and early $20^{\text {th }}$ centuries by European orientalists such as the French Clement Huart (1854-1926), the Swiss Max Von Berchem (1863-1921), and the Dutch Martijn Theodoor Houtsma (1851-1943), who compiled epigraphic evidence such as vakfiyes and manuscripts in the libraries of provincial Anatolia (Gordlevsky 1988: 22-25). Following these pioneers, Western scholars such as Paul Wittek, Friedrich Giese, and Julius Löytved published new epigraphs from the provincial cities and towns (Köprülü 1943: 380). Inspired by this European interest, a new curiosity flourished in the Ottoman Empire. After 1908, Halil Edhem (1861-1938), the pioneer of Ottoman art history, building conservation, numismatics, and museum development, studied Seljuk epigraphs from provincial Anatolia and contributed to the emerging study of the Seljuks of Rum in a sequence of articles in the journal Tarih-i Osmani Encümeni Mecmuast. (Akbayrak 2009: 475-507). İsmail Galib, his brother and a pioneering numismatist in his own right, studied coins from the Seljuks of Rum and published a catalogue entitled Takvim-i Meskukat-ı Selçukiye (İsmail Galib 1309). Ahmed Tevfik also published a catalogue of old Islamic coins, including coins from the Seljuks of Rum (Meskukat-ı Kadime-i İslamiye Kataloğu) (Köprülü 1943: 379). Manuscripts were published and serialized in the historical journals. This process was accompanied by a new interest in local histories in the provinces and in the imperial center as Western curiosity was directed towards the "local pasts". Local histories, beginning with şakir şevket's 1877 Trabzon Tarihi (History of Trebizond), Abdizade Hüseyin Hüsameddin's 1913 Amasya Tarihi [History of Amasya] and Halil Edhem's 1918 Kayseriye şehri Mebani-i İslamiye ve Kitabeleri [The Islamic Monuments and Epigraphs of Kayseri], were considerably inspired by the accounts of Western historians such as Charles Texier and Vital Cuinet. 
These local histories conveyed whatever information could be gathered from sources such as manuscripts unearthed in the local libraries, epigraphic evidence, and compilations of oral traditions. This was yet another instance of the decentralization and the "de-dynasticization" of Turkish history. Historically important cities reclaimed their forgotten grandeur via their monuments and historical heritage including the many Seljuk centers located mainly on the Central Anatolian Plateau (such as Konya, Kayseri, and Aksaray). The imposing and exclusive presence of the Ottoman Empire in the national historical imagination was dissolving.

\section{The Impact of Fuad Köprülü}

11 This was the intellectual and political setting in which Fuad Köprülü (1890-1966) delved into the study of the Seljuks of Rum. By raising a variety of problematic issues regarding the Seljuks, Köprülü's contribution to the emerging historiography of the Seljuks revolutionized historical scholarship. His disproportionate impact on the historiography recast the representations of the Seljuk polity within the national imagination, and hence has to be treated separately and extensively. ${ }^{4}$

Despite the emerging new interest in pre-Ottoman Anatolia, at the time Köprülü entered the scene it was an almost "blank sheet," not only in the Ottoman Empire but also in Europe, where the output of $19^{\text {th }}$-century orientalism was immense in other areas. ${ }^{5}$ At the time, not much was known about the Seljuks of Rum, and the lack of critical studies caused prominent scholars to accept as true erroneous ideas such as the perception of the reign of Alaeddin Keykubad III as the age of Seljuk collapse or the supposed association of Bektashis with Mevlevis (Berktay 1983b: 17-19). The German Orientalist Martin Hartmann spoke of the rule of the Seljuks of Rum in Anatolia as "a period of disorder" without any substantial evidence. Wittek remarked that not much was known regarding the Seljuks of Rum and regarded this period as merely an "auxiliary area" to assist the "main areas of study" (Gordlevsky 1988: 35). Herbert Adams Gibbons in his 1916 Foundation of the Ottoman Empire ignored the pre-history of the Ottoman Empire and began his history with a chapter entitled "A New Race Appears in History" (Gibbons 1916: 11) in which he mentioned the Seljuks of Rum only in passing. His only commentary regarding the previous two centuries was that Byzantium was too weak to respond to the Turkish invasions and thus was confined to the environs of Constantinople in Western Anatolia (Gibbons 1916: 16-17). When the young Indologist Franz Babinger at the University of Munich decided to change fields and embark on Turkish studies after working as a liaison officer in the Ottoman army during World War I, the German orientalist G. H. Becker "cautioned him about his views saying that from the standpoint of academic advancement, they [Turkish studies] were a 'sheer catastrophe'. There was no future in Turkish studies" (Leiser 1993: xiv).

The 1910s was a revolutionary decade for the study of Turkic history in the Ottoman Empire. Accompanying many unscientific articles imbued with nationalist fervor, a few exceptional and insightful works were also produced. The studies published in the Ottoman journals were awash with phrases such as "the pathbreaking developments of the last six-seven years" and "impressive works in the last six-seven years" celebrating the new dynamism in the field of 'Turcology,' a new term that began to be used to refer to studies of Turkic history. One of the objectives of Fuad Köprülü and the new nationally-minded generation was rectifying the "biased" studies appearing in Europe 
that downplayed the "historic greatness" of Turks, and restoring the rightful position of Turks in history. Turks needed to be saved from the unfavorable image they were given because of their contemporary backwardness vis-a-vis Europe.

The young Köprülü of the 1910s was a promising man of letters interested in poetry and French literature. His transfer to the field of history was prompted by his unease with the presumption held in the West that the Ottomans could not be ethnic Turks, given that Turks were not capable of founding and governing such an empire (Gibbons 1916). As a young and well-read Turkish nationalist, he committed himself to proving the genuine Turkishness of the Ottomans. The Seljuks of Rum were instrumental in this effort.

Köprülü's first article dealt with the poetry of şinasi and was printed in Servet-i Fünun in 1912 (Köprülüzade Mehmed Fuad 1328). This article was followed by a landmark article in Bilgi Mecmuası entitled Türk Edebiyatı Tarihinde Usül (Methodology in the Study of Turkish Literary History) in 1913 (Köprülüzade Mehmed Fuad 1329b: 3-52). ${ }^{6}$ This article was arguably not only a milestone in the emergence of literary history in the Ottoman Empire, but was also in the emergence of a scientific methodology in historiography. In this article, Köprülü examined the course of $19^{\text {th }}$-century European historiography and probed a wide range of historians from Vico to Seignobos. He stipulated that "Hippolyte Taine in his introduction to his reputable book on English literature wrote that the literature of a nation is her living history and nothing can be comparable to it in terms of allowing us to comprehend the history of the nation in question" (Köprülü 1986: 18-19). He shared Taine's view, and his appraisal of literature as the mirror of nations determined the contours of his later scholarly studies and interests.

After this breakthrough study, he proposed an agenda for researching the history of Turkish literature by applying the comparative methodology he suggested in his article on methodology. In that same year, Köprülü also published an article in Ikdam entitled Yeni Bir İlim: Halkiyat [A New Science: Folklore] (Köprülüzade Mehmed Fuad 1329c) and thus delved into new areas by merging his interests in literature and history, inspired by his nationalist commitments. For Köprülü, literature was not merely an intellectual pursuit to be examined by historians of literature but a key to unearth the contours of national cultures and social and national formations. He believed that the literary canons had the power to transmit the uncorrupted essences of national cultures and thus enable historians and nationally-minded intellectuals to explore and unearth their socio-cultural national heritage. He pursued this agenda in articles on Yunus Emre (Köprülüzade Mehmed Fuad 1329d: 922-930), Ahmed Yesevi (Köprülüzade Mehmed Fuad 1330: 611-645), şeyh Galip (Köprülüzade Mehmed Fuad 1329a), and a long series of articles on folk poets. From his explorations on medieval Turkish culture he jumped to a new field, devoting an article in Milli Tetebbüler Mecmuası in 1916 to the Seljuks of Rum entitled Selçukiler Zamanında Anadolu'da Türk Medeniyeti (Turkish Civilization During the Era of the Seljuks). (Köprülüzade Mehmed Fuad 1331: 293-332).

17 Köprülü's Türk Edebiyatında Illk Mutasavviflar (Early Mystics in Turkish Literature), published in 1918, was based on his previous articles. This book was his first major breakthrough, heralding his entrance into the field of history proper by leaping from literary history, an area in which he had gained immense prestige and respectability. This book may be regarded as the first comprehensive and scientific treatment of the history of Turkish literature and was praised by Turcologists such as Nemeth Gyula, Andreas David Mordtman, and Clement Huart (Palabiyık 2005: 54-56; Tansel 1976: xxii). 
Köprülü's main concern in this book was to recuperate Ahmed Yesevi, whom he regarded as the forefather of Anatolian Turkish folk literature, and to demonstrate his direct influence in Anatolia, especially on Yunus Emre, who epitomized the genuine and authentic voice of Turkish Islam and folkloric culture.

"Hereby, Yunus Emre integrated this foreign philosophical element [Persian high culture] with the original spirit of Turkish aesthetics within a national system and established a Turkish mystical literature suitable for the tastes of the people entirely different from the Persian mystical tradition. Yunus Emre epitomized the national values and aesthetics for centuries because he could synthesize and amalgamate the accumulation of centuries of national artistic spirit and comprehend the culture living in the breasts of the [Turkish] people for centuries and served the needs of the [Turkish] people" (Köprülü 1976 [1918]: 255).

Instead of extolling the pre-Islamic pagan and shamanistic heritage like some Turkists of his time, Köprülü depicted the Muslim Turks of pre-Ottoman Anatolia as devout Muslims who developed a unique, genuine, and whole-hearted way of living Islam. Contrasting the "Anatolian-Turkish Islam" with the "dogmatic and docile Arabic Islam," he argued that it was the adoption of the simple language of Turkish that Islamized the Turkic masses. For him, this mode of proselytism was more genuine and pious than a formalistic interpretation of Islam. Köprülü argued that it was the corrupting Persian influence, not Arabic, that was the main foreign element in Turkish Islamic culture. His version of "Turkish Islam" was compatible with Sunni Islam as embodied in the poetry and culture of mystical folk poet Yunus Emre. Nevertheless, he mitigated his distanced attitude to the heretical mystical sects in his previous article Selçukiler Zamaninda, where he had described them as influenced by Persian culture. ${ }^{7}$

Köprülü reconstructed "Turkish Islam" in line with his own worldview and commitments. It was not authoritarian but individualistic; not legalistic but spiritual; not based on fears of divine punishment but stemming from the love of God and nature; not desolate but joyful. ${ }^{8} \mathrm{He}$ connected the historical trajectory of the Turks from Central Asia to Anatolia via the wandering dervishes. It was as if these wandering dervishes and the mystical brotherhoods and networks had assumed the duty to transmit the spirit of Turkishness through their souls from Central Asia to Anatolia and from an earlier age to the Islamic medieval age.

21 Throughout this study, Köprülü consciously overlooked and trivialized political organizations and structures. For him, political structures and political developments were mere superstructures determined by the contours of national cultures and civilizations. What he found in pre-Ottoman and Seljuk Anatolia was the unmediated manifestation of Turkish spirituality and the "spirit of Turkishness" which could be exposed and revealed without a political organization imposing its legalism and ideology. Seljukid Anatolia was praised as the lost utopia of Turkish Islam, uncorrupted by Persian and Arabic influences. He stipulated that "while the nomadic Turcomans were being artistically inspired with the heritage of the Saga of Oghuz Khan and the [Turkish] popular literature, ... in the cities, which overflowed with Islamic scholars and jurists, Persian literature reigned ... and this culture became so prominent that it could eliminate the national religion [of Turks]" (Köprülü 1976: 233). The Seljukid court was alienated from the masses and was prone to imitate the high Persian culture to disassociate itself from the masses, whom it perceived as ignorant. Persian language and culture dominated the court (Köprülü 1976: 233-234). Köprülü thus established a 
dichotomy between the alienated court culture and the genuine national culture of the masses. In short, he exposed the living tradition of Turkish culture in the absence of an imposition from above.

There was a growing enthusiasm with an imagined Turkist utopia that had to be revived and redeemed in the 1910 s. ${ }^{9}$ Köprülü seems to discover his utopia in the Seljukid Anatolia. Nevertheless, Köprülü was not a radical Turkist praising the pure and uncorrupted volkish spirit as opposed to the corrupted court cultures. On the contrary, in many regards he was conservative, dismissing radicals who sought renunciation of the past and endorsement of Central Asian pagan Turkishness. In his later works, he attempted to reconcile his allegiance to an Ottoman vision by revealing the extent to which Turkish culture survived the Ottoman centuries in Anatolia (Köprülü 1986).

The theme of unorthodox Islam in the age of the Seljuks of Rum was also studied by Franz Babinger. His 1921 article Der Islam in Kleainasien: Neue Wege der Islamforschung (Babinger 1922: 126-152) originated as his inaugural lecture at Friedrich-Willhelms University in Berlin in 1921. Babinger argued, contrary to the received wisdom of his time, that the Seljuks were Alevis who subscribed to a heretical interpretation of Islam at variance with the Sunni interpretation of Islam. He related the Seljuks to the Safavids of $15^{\text {th }}$ century and pointed out that nowhere else in the world of Islam had local traditions been adapted as extensively as in Anatolia. He also emphasized the enormous influence of Persian culture on Turks in Anatolia. Integrating these two claims, he argued that a Turkish Islam had emerged under Persian influence and had given birth to a unique interpretation of Islam.

The Turkish translation of his article was published in Darülfunun Edebiyat Fakültesi Mecmuast [Journal of the Faculty of Literature of the University of Istanbul]that same year..$^{10}$ Köprülü immediately responded with an article published in Darülfunun Mecmuast entitled Anadolu'da Islamiyet: Türk İstilasindan Sonra Anadolu Tarih-i Dinisine Bir Nazar ve Bu Tarihin Menbaları [Islam in Anatolia: A Glance at the Religious History of Anatolia after the Turkish Invasion and its Origins]. ${ }^{11}$ In this article, he retained the perspective developed in his book Türk Edebiyatında İlk Mutasavvıflar. He criticized Babinger's and the Western orientalists' superficiality and ignorance of the local sources and rearticulated his interpretation of Turkish religion in Anatolia. For Köprülü, the Western orientalists' conclusions were erroneous due to their dearth of substantial knowledge and their superficiality. Köprülü's article was a consummate portrayal of his notion of an "organic Islam" in its original and authentic form as it was detached from the scripturalist intepretation and developed by Turks in movement throughout centuries. He endeavored to crush the orientalist vision of a "monolithic Islam" determined by the "book", Islamic learning, and a strict observance of the universally accepted principles and contrasted this legalistic Islam with the Turkish folk Islam with which he was enthralled.

Köprülü's work can be regarded as an effort to uncover the "genuine" Turkic history lying dormant beneath the superficial history of wars and dynasties as it was articulated by the Ottoman chroniclers and their modern European followers. Köprülü merged a socio-economic approach with a civilizationist understanding of history. The age of the Seljuks of Rum provided him with a perfect medium to expand on his project. His understanding of the Seljuks of Rum was Janus-faced, directed both to the past and the future. It was both a part of the Anatolian Turkish civilization and a historical juncture at which a Central Asian heritage could be reclaimed for the Turks. It was a 
historical moment in which the volkisch culture could be easily observed without the veil of political authority influenced by Arabic and Persian high cultures. The history of the Seljuks of Rum was a safe haven for those who were disgruntled with the "chronicler-style history of wars and dynasties". It was a laboratory in which Köprülü constructed a Turkish history from a non-dynastic and non-centrist perspective. As argued above, his shift of interest from literary history to the Seljuks of Rum was no coincidence. He discovered the spirit of Turkishness in a cultural milieu in which the uncorrupted cosmos of Turks reigned before the imposition of a foreign-influenced Ottoman high culture.

The Sonderweg of the Turks was a recurring agenda for Köprülü. He gradually began to be interested in legal history and attempted to situate legal history within a sociopolitical infrastructure which was, in turn, embedded within a wider and overarching civilizational background. In his 1938 article İslam Amme Hukukundan Ayrı bir Türk Amme Hukuku Yok Mudur? ${ }^{12}$ (Is There a Turkish Public Law Separate from Islamic Public Law?) he described a Turkish legal culture separate and independent from Islamic law, observable from pre-Islamic Turkic times to the Ottoman Empire. In this article, he attempted to demolish the "myth of universal Islamic institutionalism" in favor of a Turkish Sonderweg. Although he acknowledged the significance of Islamic legalism in the Turkish political institutional culture, he argued that legal culture was merely a reflection (or superstructure in Marxian terms) of social formations, thus creating space for the existence of a unique and culturally determined Turkish legal culture. He again drew a trajectory from pre-Islamic Turkic polities to the Ottomans in terms of the character of the political institutions and denied the prominence of Islamic institutionalism and legal culture.

In short, the main concern of Köprülü was to draw a trajectory of Turkic history from Central Asia to his own time. ${ }^{13} \mathrm{He}$ "emancipated" Turkish history not only from Ottoman history, but also from Islamic history. He also set the contours of a future reconciliation with Islam by distinguishing a progressive "Turkish Islam" from the alleged obscurantist Islam. He did not subscribe to the romantic Turan ${ }^{14}$ myth but endeavored to discern the Turkish culture embedded in Anatolia, in the very geography of the emerging contemporary Turkish Republic. Thus, the Seljuks of Rum were pivotal in his national historical imagination.

Nevertheless, as we will see, after the passing of the Kemalist high tide, a restoration of the Ottomans and their central position in the course of Turkish history discouraged others from proceeding along Köprülü's path. The Ottoman Empire reassumed its prestige after a short interruption by the Kemalists' anti-Ottomanist fervor. Köprülü failed to establish a school, and his erudition and research agenda failed to inspire a new generation of historians to build upon his achievements and advance the scholarly study of the Seljuks of Rum.

\section{From Seljuks of Rum to Anatolian Seljuks: The Seljuks of Rum in the Kemalist Era}

The early Turkish Republic inherited the historiographical imagination described above. This was a time when pre-Ottoman themes were seen as liberating for Turkist intellectuals, providing them with the opportunity to reveal the Turkish spirit independent of the dynastic structures of politics. Turkists cultivated an unwavering 
enmity towards the dynastic "corruption" and perceived Turkic culture as libertarian and free, in opposition to the submissive and rotten culture of the Ottoman dynastic polity and establishment. These views could be articulated more openly once the dynasty was abolished in 1922 (şapolyo 1944: 370-371; Türk Tarihinin Ana Hatları 1996 [1930]: 461-462; Mayakon 1940). For example, according to Muhittin (Birgen), "the Ottoman is the enemy of the Turk." (Birgen 2006, v. II, 630-631).

The historiographic interest in the Seljuks of Rum that emerged in the 1910s was further advanced in the first two decades of the republic. The first articles on the postSeljukid and pre-Ottoman Turcoman principalities, first and foremost the articles of Ahmed Tevfik in the Tarih-i Osmani Encümeni Mecmuast in the $1910 \mathrm{~s},{ }^{15}$ were followed by new monographs and articles in the 1920s and 1930s as a corollary to the burgeoning interest in local history. Local expressions of ethnic identity appeared not only in national journals such as Belleten and Vakıflar Dergisi but also in the state-sponsored local journals, first and foremost the journals of the local sections of Halkevleri [People's Houses] ${ }^{16}$ New local histories were published (Atalay 1339; Katip Ferdi 1331; Konyalı 1945; Konyalı 1946; Uluçay, Gökçen 1939). Apparently, these local histories were not regarded as subverting national identity and unity; on the contrary, they were viewed as reinforcing and maintaining the allegiance of localities to the grand national narrative under which they were subsumed. Local historical monuments were perceived as proving the constitutive place of these localities within the grand national narrative. ${ }^{17}$ İsmail Hakkı Uzunçarş1l published several monographs on the heritage of the Seljuks and the post-Seljukid Turcoman principalities in the provincial centers seeking to demonstrate their prominence within the Turkic history which had been trivialized by the excessive (and supposedly undeserved) emphasis on Istanbul (Uzunçarşılıoğlu İsmail Hakk1 1927; Uzunçarşılıŏlu 1929; Uzunçarşılıoğlu 1932; Uzunçarşıll 1937).

31 The name of the polity was changed in the early republic from Rum Selçuklulart ${ }^{18}$ [Seljuks of Rum] to Anadolu Selçukluları [Anatolian Seljuks] in order to further Anatolianize and Turkify the sovereign territory of Turkey by dismissing the term Rum, which connoted Greek ethnicity and might therefore support Greek claims to Anatolia. ${ }^{19}$ Before the Turkish conquest of Anatolia, Rum had meant Roman, and referred to followers of the Greek-Orthodox Patriarchy in the heartland of the Byzantine Empire; the Ottomans subsequently employed the term Rum to refer to the Anatolian peninsula as distinguished from a larger geography which also included the Balkans. During the Ottoman centuries, the Arabs had also called the Turks Rumi. This pre-national and porous nomenclature became a liability with the emergence of nationalist agendas, when Rum began to denote ethnic Greeks as descendants of the Roman Empire, making what was initially a religious term into an ethnonym.

Fuad Köprülü employed the labels Rum Selçukluları and Anadolu Selçukluları interchangeably in his monumental Türk Edebiyatinda ilk Mutasavviflar, sometimes referring to the polity as Rum, sometimes as Anadolu. In the 1966 edition, which he and Fevziye Abdullah Tansel edited, all references to the polity were rendered Anadolu Selçukluları along with other minor Turkifications in the text. In 1922, Ragip Hulusi employed the phrase Rum Selçukluları in his translation of Babinger's Der Islam in Kleinasien in the Journal of the Faculty of Literature of the University of Istanbul (Babinger 1338: 190). Interestingly, in his response to Babinger's article published in the subsequent three issues of the journal, Fuad Köprülü referred to the polity only as 
Anadolu Selçukluları, omitting the phrase Rum Selçukluları completely (Köprülüzade Mehmed Fuad 1338-1339). ${ }^{20}$ Nevertheless, this neologism was not employed by the scholarly community. Meskukatçı Ali referred to the polity as Selçukiye-i Rum in his 1924 article in the Türk Tarih Encümeni Mecmuası (Meskukatçı Ali 1340/1924:1). The 1928 yearbook of the Turkish Hearths apologetically noted that "because Anatolia was called the land of Romans (iklim-i Rum) at the time ... [the polity] was called the Seljuks of Rum in Islamic history" (Akçuraoğlu Yusuf 2009: 42). The yearbook did suggest the label Anadolu Selçukluları as a neologism, but as late as in 1929, Ali Reşat referred to the polity as Rum Selçukluları in his history coursebook for high schools (Ali Reşat 1929: 317), which was to a large extent an adaptation of the French coursebooks and thus nonnationalist in its orientation and outlook.

Rendering the Seljuks specifically "Anatolian" conformed to the recently discovered contemporary and republican "Anatolia" (Üstel 1993: 51-55). According to şemseddin Sami's magisterial geographical dictionary published in 1889, Anatolia's southern border lay along the Euphrates between Trebizond in the north and Alexandretta in the south, and its southeastern border was Kurdistan (şemseddin Sami 1307: v. I, 389) before the term "Anatolia" was reformulated to correspond to all non-European Turkey, "including historical al-Djazira, Kurdistan and Armenia" (Taeschner 1986: v. I, 462)."In a geography textbook of 1916, Coğrafya-i Osmani (Ottoman Geography), the ... territories of the empire were classified under six different regions" (Özkan 2002: 98) the first two entries of the list being (1) Anatolia or Asia Minor, and (2) Erzurum and Cezire-i Ulya (Erzurum, Van, Diyarbakır, Hakkari). In 1918, Fuad Köprülü referred to "Eastern Anatolia" seemingly implying Cezire-i Ulya, while he associated Manzikert with the subsequent Turkish invasion (Köprülüzade Mehmed Fuad 1918: 208). We encounter the first effort to include all of the territories legitimately claimed by Turkey under the rubric of Anatolia in Hamit Sadi's table, which divided Anatolia into nine regions, including "Eastern Anatolia" and "Southeastern Anatolia", to cover the regions previously not included within the geographical region "Anatolia" (Özkan 2002: 99-100). Although Hamit Sadi's division was reinforced by similar topographical divisions, the old topographical demarcations were yet to be obliterated. Faik Sabri in his 1929 Türkiye Coğrafyast (The Geography of Turkey) was loyal to the historical and geological rationales and divided Turkey into (1) the Thracian Plateau, (2) the Anatolian Plateau (2) the Eastern Plateaus (şark Yaylaları) (Faik Sabri 1929: 23-60, 96-110, 256-278). Furthermore, in the official Kemalist history textbook published in 1931, we encounter "Armenia" as a geographical territory which lays west of southern Caucasia and seems to cover modern Turkey's northeast (east of Erzurum) given that the textbook states that in the $11^{\text {th }}$ century "Armenia was trampled by the Turks. Defeating the Byzantine armies, Turks reached Erzurum" ("Ermenistan Türkler tarafindan çiğnendi, Türkler Bizans orduların mağlup ederek Erzurum'a kadar ilerlediler") (T.T.T. Cemiyeti 1933: 226). The textbook refers to Armenia once more, this time associating the military activity in Armenia with the "destruction of Malatya" (T.T.T. Cemiyeti 1933: 227). Nevertheless, the rhetoric of "the unity of the Anatolian Turks", which was attained at certain historical junctures (such as the establishment of the Seljuks of Rum, the rise of Ottomans and the defeat of the Greeks, and the end of Greek and Allied occupation in the National Struggle in 1922) and dissolved at other historical junctures, is a key theme in this official textbook (T.T.T. Cemiyeti 1933: 278). 

historical role models of the Ottoman Empire. In İsmail Hakkı Uzunçarşıll's
presentation to the second Turkish History Congress in 1937, he referred to Köprülï's remarkable study on the origins of the Ottoman institutions in which Köprülü had repudiated the claims of Western Ottomanists regarding the alleged impact of the Byzantine institutions on their Ottoman counterparts (Köprülüzade Mehmed Fuad 1931). Uzunçarşılı supported Köprülü's conclusions and argued that after the collapse of the Seljuks of Rum, the Turcoman principalities had modeled their polity and governance on the model of the Seljuks and the Ilkhanids (Uzunçarşılı 1943: 500). He briefly discussed the administrative structures of the post-Seljukid Turcoman principalities of Germiyan, Karamanl, and Karesi and posited them within the culture of Islamic legal institutionalism which they inherited from the Great Seljuks and the Seljuks of Rum. Uzunçarşıll thus concluded that the European argument regarding the Byzantine origins of the Ottoman institutions was refuted by the evidence he provided regarding the institutional culture of the Turcoman principalities (given that the Ottomans were also a Turcoman principality that emerged with the collapse of the Seljuks of Rum). This relatively short paper was largely theoretical and lacked substantial evidence. In Anadolu Beylikleri ve Akkoyunlu, Karakoyunlu Devletleri [Anatolian Principalities and the States of Akkoyunlu and Karakoyunlu] published the same year, Uzunçarşıll presented a more thorough study. In this study, he utilized vakfiyes, Arabic and Turkish language manuscripts and local histories written in the $14^{\text {th }}$ and $15^{\text {th }}$ centuries while the memories of these principalities were still alive (Uzunçarşıll 1937). In the first, chronological part of the book, he summarized political history, whereas in the second part he dealt analytically with the social and economic conditions of the principalities in Anatolia. In this latter part his main concern was clearly to prove and further Köprülü's thesis (Uzunçarşşlı 1941). Uzunçarş̧ll's interest in socio-economic history was inspired by Köprülü, but lacking Köprülü's erudition and comparative methodology, Uzunçarşıılı was prone to essentialism and legalism and tended to assume that legal institutions on paper both revealed and determined political, social, and economic organization and development.Nevertheless, this study was a major contribution at a time when the Turcoman principalities were a black hole in academia. 21

Certain themes pertaining to the age of Seljuks attained prominence in the Kemalist historiography. The translation of Ibn Battuta's travelogue into Turkish by Mehmed şerif Pasha in 1897-1901 (İbn Battuta 1328) (following a partial translation serialized in Takvim-i Vekayi and subsequently published as a separate book (Aykut 2004: v. I, xlvi-lii; Ibn Battuta 1290)) engendered profound interest in the previously unnoticed akhis, the brotherhoods of craftsmen in Seljukid and post-Seljukid Anatolian cities. This travelogue, in which Ibn Battuta conveys his encounters with akhis during his travels in 
Anatolia, is the best source on this peculiar pre-Ottoman Anatolian institution. Akhis were first extensively studied by Fuad Köprülü in his 1918 Early Mystics in Turkish Literature as representative of the freedom-loving Turkic political culture imbued with the teachings of Turkish esoterism (as opposed to the literal interpretations of Islam in courts). The implications of the peculiar akhi institution were widely discussed in academic circles, ${ }^{22}$ and also inspired the emerging nationally-minded intelligentsia to endorse it enthusiastically. The akhi institution was praised immensely by the republican intelligentsia, who saw it as epitomizing a Turkic semi-republicanism which apparently enjoyed significant power in cities after the Mongol invasions and the breakdown of political structures. More importantly, Ankara, the capital of the new republic, was supposed to have been a medieval city-state self-governed by the akhis before the Ottoman takeover (Uzunçarşılı 1945: 40-41; Koşay 1932: 22; Gülekli 1948:49; Galanti 1951: 49-50; Ahmed Tevfik 1329 1200-1204; Halil Edhem 1332: 312-312). Akhis were examined in various books, articles and pamphlets in the 1940s, some academically robust and others meager propaganda work. Whereas the prolific scholar Abdülbaki Gölpınarlı produced an exhaustive and meticulous study of the akhis, (Gölpınarlı 1949-1950: 3-354) others, such as İlhan Tarus, perceived them as precursors of the republic who "lived within a democratic system" (Tarus 1947: 45). Neşet Çağatay tellingly named his book on these fraternities as "Akhis as a Turkish National Institution" (Çağatay 1974).

Nevertheless, one may legitimately argue that the interest of Kemalist historiography in the Seljuks of Rum remained scant despite the ideological vistas it offered the Republican regime. The reason why the Republican elite did not advance along the path opened by Köprülü can be discerned in Aziz şevket Kansu's (1903-1983) paper presented to the second Turkish Historical Congress in 1937 (Kansu 1943: 440-456). Kansu was a medical doctor and physical anthropologist (and later the chairman of the Turkish Historical Association between 1962 and 1973). His paper was a presentation of his studies concerning the measurement of skulls conducted at different historical settlements in line with the racist anthropological methodology of the 1930s. Kansu had two sets. The first set was a collection of skulls retrieved from an ancient Anatolian settlement from the Hittite and pre-historic ages, and the second set was gathered from an excavation at a Seljuk settlement near the town of Selçuk in western Anatolia. Presenting exhaustive tables with the precise measurement of the sculls, Kansu demonstrated that the two sets matched each other. In light of this anthropological evidence, he concluded that the Seljuk Turks did not bring a new racial character to Anatolia. He argued that "it is not true that Turks changed the racial makeup of Anatolia. When the Seljuks reached Anatolia and marched from East Anatolia to the Aegean coasts, there had already been a majority of Alpine, that is proto-Turkic, human elements there since proto-history" (Kansu 1943: 456). Kansu then quoted Albert Gabriel, who praised the high standards of Seljuk art and concluded that "far from being followers of a foreign school, the Seljuk art displays such creativity and originality that Turks can see the artistic work of the XII and XIII centuries as a legacy of their magnificent past" (Kansu 1943: 450). Interpreting Gabriel's commentary on artistic continuity as a proof of "racial continuity", this (pseudo-)scientific anthropological survey "confirmed" that Turks were an autochthonous race that had not arrived in Anatolia later than one thousand years ago, and that Seljuks were merely another Turkish group that reached Anatolia following the migration paths of the earlier Turks (Kansu 1943: 456). 


\section{The Creation of the Myth of Manzikert} defeated by the Seljuk army and the Byzantine emperor was captured. Yet Manzikert was not a pre-planned strategic victory for the Seljuks. The Seljuk leader Alparslan did not aim to attack and destroy the ambitious Byzantine army; his attack was rather a defensive measure before moving to his main combat ground in the south to face the Fatimids for supremacy within the abode of Islam at a time when the Byzantine army was striving to impede the continuous Turcoman raids that had been ravaging the eastern frontiers of Byzantium since the 1050s. The conclusive victory also did not cause Alparslan to take advantage of this defeat and seek territorial expansion. As Claude Cahen, the eminent authority on Selkjuks of Rum wrote, “Alp Arslan's object was not to destroy the Byzantine Empire; he contented himself with frontier adjustments, the promise of tribute and an alliance-settlement which the downfall of Romanos Diogenes rendered impermanent" (Cahen 1986: 420-421). Nevertheless, what followed the war was the rapid Turkification and Islamization of Anatolia. "This was due to the internal political disorders in the Byzantine polity. The domestic conflicts of the Byzantines not only encouraged Turcomans to raid the west of Cappadocia, but also allowed them to take hold and settle in these lands" (Cahen 1992: 26). The Turkification and Muslimization of Anatolia occurred within two centuries, mainly in two waves: the first in the second half of the $11^{\text {th }}$ century and the second in the mid-1 $13^{\text {th }}$ century due to the flight from the Mongols. Thus, Manzikert paved the way for a dramatic process of Turkish colonization and transformed the demography of Anatolia, a process which has yet to be explained satisfactorily in the absence of substantial evidence. ${ }^{23}$

The origins of the Manzikert myth lie in political developments of the early $20^{\text {th }}$ century. The loss of Roumelia in the Balkan Wars inspired a new interest in Anatolia, which was rendered the "homeland of the Turks". It also arguably emerged as a reaction to the utopian Panturkism and visions of mythical Turan, which some regarded as an artificial construct promoted by the Tatar intellectuals who had settled in Istanbul after 1908. In this conjuncture, a new emphasis on Anatolia and a Turkish identity embedded in the Anatolian geography emerged. One exponent of this position was Yahya Kemal (1884-1958). As we learn from Yakup Kadri Karosmanoğlu, in the 1910s Yahya Kemal was contemptuous of the empty rhetoric of the Turanists. Turks of a distant geography and past held no interest for him, and he showed no affinity for pre-Manzikert Turkic history, regarding it, at best, as a prelude to Turkish history (Tanpınar 1995: 33). Protesting the "crude nationalism" of Ziya Gökalp, he subscribed to a romantic nationalism, and dismissed historical epics with the motto "I am future rooted in the past" (Karaosmanoğlu 2000: 122). Yahya Kemal articulated his position during the National Struggle in Dergah, a journal published in Istanbul during the Allied occupation (1918-1922) by a group of young intellectuals "who came together not due 
to close intellectual affinities, but due to the shared trauma of the Balkan Wars and the enthusiasm for the National Struggle" (Tanpinar 1995: 33-34). For Yahya Kemal, the Kemalist movement in Ankara had risen to defend an Anatolian nationalism against the discredited Turanism of the 1910s. The journal Dergah was published in Istanbul during the Allied occupation (1918-1922) by a group of young intellectuals "who came together not due to close intellectual affinities, but due to the shared trauma of the Balkan Wars and the enthusiasm for the National Struggle [in Anatolia]" (Tanpinar 1995: 33-34). For Yahya Kemal, Turkish history began with Manzikert; the mixing of blood after Manzikert created the conditions for the emergence of a new nation. It was Manzikert that made the Turks and not vice versa. Highly influenced by Michelet's perception of Frenchness and French history in contrast to the racial and ethnic understanding of "nation" prevalent among the Young Turks in the 1910s, Yahya Kemal's vision was a harbinger of Kemalist nationalism and nation-statism. With the Turkish retreat during the later years of World War I, a similar reaction against the Turanist aspiration emerged within the Turkish Hearths by those who defended a Turkish homeland strictly confined to Anatolia (Üstel 1993: 51).

The "myth of Manzikert as the moment of the opening of Anatolia to the Turks" was invented in the early $20^{\text {th }}$ century within this intellectual milieu to serve these concerns. Although Manzikert was already venerated as a Muslim epic in 19th-century Ottoman historiography, its depiction as the "battle that opened Anatolia to Turks" was novel.

Abrurrahman şeref had mentioned the war as "the war near Manzikert" in which the "Roman emperor Roman Diogenes was defeated and taken captive" without any reference to the "opening of Anatolia" (Abdurrahman şeref 1315: v. I, 47), although he did establish that "Alp Arslan took Georgia, South Syria, and Mesopotamia" (Abdurrahman şeref 1315: v. I, 47). Ahmed Cevdet also did not charge the war with any substantial attributes in his History, mentioning only the defeat of the Byzantine army and the captivity of Roman Diogenes (Ahmed Cevdet Paşa 1309: v. I, 26). In his Kısas-ı Enbiya (The History of the Prophets), the picture he drew was slightly different. Since the book was an Islamic history and aimed to encourage patriotism among a larger audience, he devoted long passages to the Battle of Manzikert, re-articulating the Islamic hagiographic tradition as developed in the chronicles of the $12^{\text {th }}$ and $13^{\text {th }}$ centuries and praising Alp Arslan as a just, benevolent, and heroic Islamic ruler (as all the other revered Islamic political leaders and commanders were defined). Nevertheless, he did not make a single reference to the "opening to Anatolia" (Ahmed Cevdet Paşa 1969: v. II, 241-242). For Ahmed Cevdet, Alp Arslan was an Islamic, not Turkic hero. In Leon Cahun's 1896 Introduction à l'histoire de l'Asie, (Cahun 1896) a breakthrough study which influenced the Turkists of the Hamidian era extensively and is thus constitutive of the historical imagination of the Turkists, Manzikert was not mentioned at all. Necib Asım, in his Türk Tarihi, which was overwhelmingly based on Leon Cahun's book, completely secularized and ethnicized the battle and described it as "an immense and definite success" [büyük ve kati bir muvaffakiyete nail olan] (Necib Asım 1316: 271). He quoted the alleged dialogue between the captured Roman emperor and the Seljuk sultan to demonstrate the latter's magnanimity (Necib Asım 1316: 272), but he attributed no dramatic meaning to the battle, nor did he mention its consequences. ${ }^{24}$ Ahmed Refik devoted significant space to the Seljuks of Rum in his magisterial Tarih- $i$ Umumi [General History], a fact indicative of the growing interest in the pre-Ottoman 
Anatolian Turkish civilization in the early 1910s. His depiction of the Battle of Manzikert was also completely secularized and Turkified (Ahmed Refik 1328: v. VI, 279-280). Nevertheless, he did not credit Manzikert with any substantial repercussions. For him, the Turkification of Anatolia was associated with the conquests of Süleyman bin Kutalmış in the 1070s. He began his long chapter on the Seljuks with Süleyman bin Kutalmış's ascent to the throne as the son and successor of Alparslan. The area bestowed upon Süleyman bin Kutalmış was defined as "between the Euphrates and the Black Sea Channel [Bosporus]", not as Anatolia (Ahmed Refik 1328: v. VI, 286). The chapter also did not single out the Battle of Manzikert as the crucial turning point of the Turkish invasion. He wrote, "the control of the Byzantine Empire had already been weakened because of the assaults of the caliphs and the battles of Tugrul Bey and Alparslan" (Ahmed Refik 1328: v. VI, 286).

Only in 1918 did Fuad Köprülü establish a connection between Manzikert and the Turkish invasion of Anatolia. "Completely defeating the Roman emperor Romanos Diogenes in the Battle of Manzikert, [Alparslan]... established absolute Turkish rule in Anatolia [Anadolu'da Türk hakimiyetini mutlak bir suretle kurdu]." (Köprülüzade Mehmed Fuad 1918: 208) In 1922, he referred to the battle as "the definite victory of Manzikert" in Turkifying Anatolia (Malazgirt zafer-i kat'isi) (Köprülüzade Mehmed Fuad 1338: 282). In his 1926 History of Turkish Literature he wrote, "the victory in Manzikert opened all the paths to Anatolia" (Köprülü 1980). This view became the unquestioned orthodoxy with the Kemalist intervention into Turkish historiography beginning in 1930 (Akbayrak 2009: 368-376; Ersanlı 2003: 119-120; Copeaux 1997: 54-61; İ̆gdemir 1973).

In Mükrimin Halil Yinanç's 1934 History of Turkey: Age of the Seljuks, Manzikert was consecrated not only as the turning point in Turkic history, but also "a turning point in world history" (Yinanç 1944: 78).Staff officer Feridun Dirimtekin wrote in his "military history" of the Battle of Manzikert published as the supplement of Military Journal in 1936 that "Seljuk commanders conquered Sivas, Kayseri, Bursa, Ankara and the Aegean coasts...Anatolia was Turkified. That meant the end of Byzantium" (Dirimtekin 1936: 48). ${ }^{25} \mathrm{He}$ also compared Manzikert with the Battle of Cannae, the decisive defeat of the Roman army by the Carthegian army under Hannibal which was praised by Hans Delbrück, the most reputed German military historian in pre-1914 Germany, Alfred Von Schlieffen, the eminent strategist and chief of the Imperial German General Staff from 1891 to 1906, and the Prussian military historians in general as the ultimate battle of annihilation (and an inspiration for the Schlieffen Plan and Blitzkrieg) and spectacular tactical genius (Dirimtekin 1936: 1). His comparison and depiction of the war as the "Turkish Battle of Cannae" clearly epitomized the new cultic status of the war in the eyes of the nationalists and Kemalists deeply influenced from Prussian visions of total warfare, militarization of the nation and militarism. Dirimtekin also began his military study of Manzikert rendering it as a "turning point in world history" (Dirimtekin 1936: 1). The reiteration of this cliché will recur verbatim in all the later treatments of Manzikert (Turan 1971: 32; Sevim 1988: 75; Sevim, Merçil 1995: 72).

Mükrimin Halil Yinanç was one of the proponents of the Anatolian ideology in the 1920s and emerged as a pioneer in the scholarly study of the Seljuks of Rum in Turkey. He gathered and carefully scrutinized manuscripts pertaining to the era in various languages (Ülken 1961; excerpted in Alpayer, Özatalay 1962: 52-53). In line with the premises of Kemalist historiography, he proposed a radical new historical periodization of Turkish history. He developed his periodization as early as 1924 in an article in the 
journal Anadolu Mecmuast in which he rendered the six centuries of the Ottoman Empire into a mere phase among others in the history of Anatolian Turkishness (Üstel 1993: 52). In this later, more scholarly studies, he retained his periodization of the "History of Turkey" [Türkiye Tarihi] - a phrase introduced by Kemalist historiography - beginning with "the opening of Anatolia by the Turcomans, who were one of the most populous branches of the Turkish race and who deemed it their own land [yurd]" (Yinanç 1944:1). The first age of Turkey was "the age of establishment, formation, settlement, and unification" which covered the reign of Seljuks of Rum. This was followed by the "age of interregnum and lords of the valley" [fetret veya müluk-i tavaif devri] before the Ottomans reestablished Anatolian and Turkish unity. As is clear from the names given to the eras of Anatolian history, the phrase Türkiye Tarihi marginalized the Ottoman Empire despite its imposing six-century-long presence and rendered it a mere phase of the History of Turkey beginning in 1071, the annus mirabilis of both Turkish history and the history of Turkey.

\section{The Rise of the Myth of Manzikert and the Turco- Islamic Synthesis: Two Visions of Medieval Post- Manzikert and Seljuk Anatolia}

Manzikert did not acquire the prominence in the Kemalist historiographical canon that it would attain later. It gained prominence only with the emergence of the composite of Islamic and nationalist ideas known as the "Turco-Islamic synthesis" beginning in the late $1960 \mathrm{~s}$, as the $900^{\text {th }}$ anniversary of the battle approached. The anniversary was celebrated in 1971 with a great fanfare, including the minting of coins and issuing of stamps (Hillenbrand 2007: 216-219). Books were published not only on the Battle of Manzikert but also on the Seljuks of Rum in general, ensuring that 1971 would leave its mark on the historical imagery of the next two decades (Aslanapa et al. 1971; Bilgiç 1971a; Alptekin 1971; Arık 1971; Dilaver 1971). It was an opportune moment for the battle to appear under the spotlight because it served to demonstrate the historical authenticity of the Turco-Islamic persuasion, although it may be argued that the merging of ecumenic Turkic and Turco-Islamic history with a Kemalist vision of history confined strictly to Anatolia exemplifies the contingent power of history and historical metaphors over contemporary discourses and ideologies.

This persuasion matured in the 1970s, fostered by conservative right-wing intellectuals who reconciled Turkish nationalism with Islam. Repudiating the strictly secular interpretations of Turkish nationalism, they argued that Islam and Turkish identity were indistinguishable and complemented each other. ${ }^{26}$ Inspired by the vision of Ziya Gökalp (1876-1924), the revered ideologue of Turkish nationalism and Kemalism, they imagined a "Turkish culture" uncorrupted through the ages and embodied in the Turkic states, and argued that the Turkish nation was grounded in this cultural uniqueness rather than on racial superiority. The culturalistic turn enabled the insertion of religion as one among many other components of Turkish culture. The proponents of the Turco-Islamic synthesis thus endorsed the nation-statist discourse of Kemalism and reconciled it with Islam, merging their Kemalist training in the "center" with their provincial backgrounds. The short biographies of the two architects of this idea are illustrative. 

Tefenni in the province of Burdur (Leiser 1988: 13) and Turan in Soğanlı, a village near Trabzon (Demirci 1995: 8). They both came from rural lower-class families and owed their upward social mobility to their training in the prestigious academic institutions founded by the Kemalist regime in the 1930s to train the new generation of scholars. They acquired their bachelor degrees in Ankara at the newly established Dil Tarih Coğrafya Fakültesi [Faculty of Language, History, and Geography] and took over the work of the preceding first generation of Kemalist historians. This geographical and cultural expansion process, whereby country boys were requited, equipped with intellectual capital and utilized to convey the message of Kemalism, widened Kemalism's accessibility and reception. Although the message was significantly modified in certain aspects, the continuities were also remarkable.

49

important site for the development of the Turco-Islamic synthesis (Copeaux 1997:

$$
\text { 95-100). The institute's journal, Türk Kültürü (Turkish Culture) was particularly }
$$
prominent in the articulation and advancement of the theory. İbrahim Kafesoğlu (1914-1984) one of the foremost historians of the Seljuks, emerged as the chief ideologue of the institute, and endeavored to construct a new historical imagination that would reconcile the Turkish nation and culture with Islam (Kafesoğlu 1955: 463-490; Kafesoğlu 1966: 467-480; Kafesoğlu 1972). He was not only a prolific writer but also an adroit organizer of symposia and congresses gathering "nationalist intellectuals" (Taşkın 2007: 135-143). He was also the founder and the first chairman of the "Hearth of the Intellectuals" (Aydınlar Ocağı), a highly influential right-wing thinktank in the 1970s and the chief bastion of the Turco-Islamic Synthesis. ${ }^{27}$

Interestingly, many of the prominent proponents of the Turco-Islamic persuasion, including İbrahim Kafesoğlu, Osman Turan (1914-1978)28 and Mehmet Altan Köymen (1914-1993), (Köymen 1976; Köymen 1989) were scholars of the Seljuks and the Seljuks of Rum, and were at the same time also right-wing intellectuals and leading Seljuk historians. Although they began to produce their early work in the late 1940s and 1950s (Köymen 1947; Turan 1948a; Turan 1948b; Turan 1952; Kafesoğlu 1956; Erzi 1956; Köymen 1962), they rose to prominence in the second half of 1960s along with the rise of a new conservative intelligentsia. Kafesoğlu's entry in İslam Ansiklopedisi [Encylopedia of Islam] as a separate 24-page pamphlet provided the outline of the nascent discourse. Kafesoğlu praised Alp Arslan as "exterminating the currents detrimental to Sunni Islam", "maintaining political unity" and guiding the Turks to their promised land, Anatolia, on an Islamic and historical mission (Kafesoğlu 1956:1). With Kafesoğlu, Alp Arslan was promoted to a senior in the pantheon of great Turkic heroes along with Atatürk and Mehmed II. Historians with Turco-Islamic sensitivities founded the Selçuklu Tarihi ve Medeniyeti Araştırma Enstitüsü [Institute for the Research of Seljuk History and Civilization] in 1966 and published a scholarly journal devoted to studies in Seljuk history (Selçuklu Araştırmaları Dergisi) (Bilgiç 1971b: vi).

As the $900^{\text {th }}$ anniversary of Manzikert approached, the battle came to the limelight and was further consecrated. In the words of two prominent proponents of the TurcoIslamic synthesis, with Manzikert, "Anatolia's eternal destiny was sealed with its transformation into a Turkish homeland (yurd)" (Kafesoğlu, Deliorman 1977: 66; Sevim 1988: 58-76; Turan 1971: 32-37; Köymen 1992: v. III, 26-40). Furthermore, these historians gave their own twist to the Kemalist interpretation of Manzikert. ${ }^{29}$

European Journal of Turkish Studies, Complete List 
52 In one respect, what the Turco-Islamic hagiographers of Manzikert did was simply return to the "origins", discovering the sources and reiterating them verbatim and thus re-Islamizing Manzikert after its portrayal in the Kemalist canon as an ethno-racial war. Faruk Sümer and Ali Sevim gathered relevant Islamic sources on Manzikert (Hillenbrand 2007). Their study included thirteen accounts, including the relevant chapters of Rashid-el-Din's Jami-ul-Tawarikh. The thirteen accounts gathered by Sümer and Sevim to a large extent replicated each other. Although none of these sources were contemporary with Manzikert (many of them written one or two centuries later), Cahen noted that the Muslim/Arabic sources regarding Manzikert are in agreement with accounts of the Byzantine commanders who participated in the battle (Cahen 1934: 617-642 quoted in Copeaux 1997: 191). The discourse prevalent in these accounts is emblematic of the Islamic gaza literature, juxtaposing upright and victorious Muslims with barbaric infidels. Ibn al-Athir wrote in his al-Kamil fi al-Tarikh, "poets had praised Alp Arslan and repeatedly commemorated this victory" (Sümer 1988: 27). Likewise, Ibn al-Djawzi wrote "when the news reached Baghdad, drums and horns were played. People gathered in beyt al-nuba. The letter of victory was read aloud" (Sümer 1988: 17). Arguably, Ibn al-Athir's and other authors' accounts derived from these epic oral traditions. These accounts conveyed in detail the spectacular narrative of the captivity of Roman Diogenes and his freeing by the magnanimous Alp Arslan. The most poignant narrative tradition was conveyed in Rash-ed-din's account.

53 Whether this victory made such an impact in the consciousness of the Muslim public opinion cannot be known. However, one thing is sure: By documenting the contemporary eulogies of the Battle of Manzikert, the proponents of the Turko-Islamic synthesis re-constructed the myth of Manzikert as an Islamic epic. ${ }^{30}$ This epic narrative established itself as the only truthful narrative and obliterated any possible alternative narratives of the battle. ${ }^{31}$ Hence, in the modern Turco-Islamic narrative of Manzikert, we do not observe any significant historical misrepresentations or distortions. On the contrary, the salient point is the accordance between the discourses of the Islamic contemporary accounts and the modern Turco-Islamic narrative of Manzikert. Providing evidence to Anthony Smith and his ethnosymbolic approach to nationalism (Smith 1991; Smith 1999; Smith 1986; Smith 2003), the Turco-Islamists reinvigorated the contemporary accounts of the Battle of Manzikert, and out of these popular mythologies, they invented a modern Turco-Islamic imagination and narrative.

The prominent role attributed to Manzikert arguably derived from its Janus-faced character. Manzikert contained allusions to a Turkish nationalism both Anatoliacentered and ecumenical. It had two faces, the first directed towards the pre-1071 world of Turks and the other looking at the post-1071 world of "Western Turks" in Anatolia. We may argue that Manzikert was a conspicuously Kemalist project although its heyday came long after Kemal Atatürk with the rise of the historians of the TurcoIslamic synthesis school. ${ }^{32}$ Manzikert connected two different Turkic cosmologies and drew a path from the legendary Oghuz Khan (the first Turk and the first Turkish khan in the Turkish mythology) to Atatürk by simultaneously alluding to the ecumenical vision of Turks and to the sacralization of Anatolia. It was the intersection and marriage of two different historical imaginations.

The contemporary accounts of the battle were reconstructed through a Kemalist lens which reinterpreted the medieval warfare and statecraft within the terminology of perfectly organized, Weberian, modern nation-states. Etienne Copeaux has 
demonstrated the extent of the Kemalist elements in this gaza epic narrative introduced in the 1970s as most apparent in the implicit or explicit allusions to Atatürk in the depictions of Alparslan throughout the epic gaza narrative introduced in the 1970s (Copeaux 1997: 191). ${ }^{33}$ The resemblance of the dialogues between the victorious Alparslan and the captive Roman emperor Roman Diogenes to the dialogue between the victorious Mustafa Kemal and the captive Greek commander Trikupis in 1922 are unmistakable. The refashioning of Manzikert in the 1970s marked a perfect moment for the reconciliation of Kemalism and Islamic discourse at a time when the chief enemy of the republic emerged as the communists.

The Kemalist narrative was the Ur-ideology and the "root paradigm" of modern Turkish political culture from which all the modern ideologies from socialism to Islamism derived their premises. This is also true for the Kemalist representations of Turkish history. Nevertheless, there are salient differences between the Kemalist and the Turco-Islamic depictions of post-Manzikert and Seljuk Anatolia. Due to lack of space, we will not comparatively scrutinize the scholarly output of these two schools ${ }^{34}$ but will instead attempt to reveal the differences as they appear in the history textbooks which, because they were written with pedagogical aims, best exemplify the ideological premises.

Tarih II, the authoritative Kemalist high school text book published in 1933,discussed the clashes with Georgians and Armenians during the Turcoman raids into Anatolia (T.T.T. Cemiyeti 1933: 226). All references to Armenians and Georgians disappeared in the history textbooks of the 1970s, which portrayed these raids as targeting the Byzantine Empire and imagined the Byzantine Empire as a perfectly centralized polity monitored strictly from Constantinople. In Tarih II, by contrast, the fragility and tributary nature of the Byzantine central state was captured well. As articulated in the Kemalist course book, during these raids, the Turcoman lords plundered nearby cities and fought not with the forces of the Byzantine central authority, but with local, autonomous commanders. After the Byzantine military and political presence had been weakened in these remote outposts, the Byzantine East was run by local warlords of predominantly Armenian and Georgian origins. It can be argued that later textbooks ceased to emphasize the Turcoman raids so as not to invoke the non-Turkish autochthonous ethnic groups living in Anatolia prior to Manzikert. In the 1930s, the memories of the ethnically mixed character of Anatolia before the 1920s were fresh, in particular of the Armenians and the Armenian massacres. Time was necessary for the "forgetting process" which formed one of the main components of the "construction of national memory". ${ }^{35}$ Furthermore, the consolidation of state-centrism (as opposed to Turkism) had yet to be completed in the 1930s, a period which was marked with inconsistencies and ambiguities. ${ }^{36}$

We may legitimately argue that in Tarih II, the cult of the state was not yet consolidated. Instead of portraying the nation as strictly defined by its submission to a political authority that claims to represent it, Tarih II promoted a racialized notion of nation. The image of Turks fighting against and defeating Armenians and Georgians was also arguably in accordance with social Darwinism's understanding of ethnicoracial wars and struggles.

59 The rupture in the representations of nation and state in Turkish history can be observed in the liberal-nationalist history textbooks written in the late 1940s and 1950s by authors such as Emin Oktay and Niyazi Akşit ${ }^{37}$ as replacements for the Kemalist 
history textbooks. In these textbooks, the Seljuk raiders were depicted as modern military commanders taking and executing orders from the central political authority. "Kutulmuş oğlu Süleyman Bey was assigned [memur edildi] to conquer the lands to the west of Kizılırmak." (Oktay 1951: 173). The book trivialized and marginalized the principalities established by the Turcoman raiders and implied that Kutalmışoğlu Süleyman, by establishing an effective and centralized state in such a short time, secured the "unity of Anatolia" [Anadolu birliği], that sacrosanct phrase and cult of Turkish nationalism and nation-statism (Oktay 1951: 173).

This view was reinforced by the Turco-Islamic textbooks published in the 1970s. In these books, the post-Manzikert Turkish invasion was further centralized and depicted as a top-down venture. This process was narrated employing anachronistically modern military terminology. According to İbrahim Kafesoğlu and Altan Deliorman, Turcoman lords, who were dubbed "commanders" as if they were military officers of a modern military ${ }^{38}$ carried out military operations in all parts of Anatolia on orders of Alp Arslan: "[Alp Arslan] ordered the Turcoman lords to capture all of Anatolia" (Kafesoğlu, Deliorman 1977: 66). ${ }^{39}$ The authors described these marches in detail and dubbed these raids "military operations" (harekat) coordinated by a joint chiefs of staff: Operation Southeastern Anatolia, Operation Western Anatolia, Operation Eastern Anatolia, Operation Middle and Northwestern Anatolia (Kafesoğlu, Deliorman 1977: 68-73; Sevim 1988: 42-45). According to the textbook, whereas the Seljuks of Rum had been established legitimately upon the orders of Alp Arslan as an extension and dependency of the Seljuks after Manzikert, "the Turcoman principalities were [temporarily] founded due to a power vacuum [iktidar boşluğu]", (Kafesoğlu, Deliorman 1977: 109) as if their establishment was a diversion from the natural path and a temporary stage within the pre-ordained trajectory of (Turkic) history.

With the complete victory of the cult of the state over ethnic romanticism, ethnic references were also marginalized, and the narrative was reconstructed as a struggle between the Turkish political leadership and the Byzantine Empire. According to Osman Turan, once the Byzantines had been subdued militarily and politically, Anatolia was easily Turkified and Islamized (Turan 1973: 51). He saw the Turkish raids as part of a master plan for the Turkish conquest of Anatolia derived from a "Turkish ideal of world domination" [Türk cihan hakimiyeti mefkuresi], the foremost motivation of Turks in history (Turan 1969b). The Turkish raids and plunders were no longer seen as spontaneous, as had been implied in Tarih II. Now the Turkish race was imagined as an organism with one brain and single command unlike the Kemalist romanticism which had praised the free-standing "noble raiders" fighting for their own glory, fame, and honor although subservient to the Turkic ideal in the final analysis. For Kafesoğlu, Turcoman nomads "came from distant steppes never to return, and submitted to the Seljukid state. Coordinated and guided by the state, they flooded into Byzantium with Islamic zeal and heroism" (Kafesoğlu 1956: 1-2). Arguably, state-centrism had won over a racialized vision of history, much as it had in the $19^{\text {th }}$-century Europe, where romantic nationalism had been absorbed by the rising nation-states, especially in Germany where the early- $19^{\text {th }}$-century pre-Christian pagan mythologies had been absorbed by Prussian authoritarianism. ${ }^{40}$ Hence, the struggles against the "Armenian and Georgian" were replaced by struggles with the Byzantine Empire.

The depiction of the emergence of the first principalities was also different in these history textbooks. Whereas in the coursebooks of the 1970s, the emergence of the 
principalities founded by the Seljuk raider commanders in post-Manzikert Anatolia (Danişmenids, Artukids etc.) was downplayed and marginalized, in Tarih II the princes were perceived as audacious warlords who had legitimate rights to hold on to their dominions. The raider-commanders were seen as considerably independent authorities. Central authority was yet to be consecrated as indivisible, incorruptible, and the embodiment of Turkishness within a discourse of the "eternal state" [ebed müddet devlet]. According to Tarih II, "the unification [vahdet] of Anatolia had been achieved as late as during the reign of Kilıçarslan II (1156-1192)", (Deliorman 1988: 232) and the era between 1070s and circa 1200s was dubbed "The Era of the First Seljukid Feudalism" (T.T.T. Cemiyeti 1933: 228). According to the history textbooks of the 1970s, by contrast, the "unity of Anatolia" had been achieved rapidly by Kutalmışoğlu Süleymanşah's defeat of the insurgent but weak commanders who had temporarily succeeded in running their dominions. The competition between the Seljuks of Rum and Danişmenids for the domination of Anatolia demonstrated in Tarih II is missing in the history coursebooks of the 1970s.

63 Another difference between Tarih II and the history textbooks of the 1970s was their portrayal of the economic order. The 1970s coursebooks described a top-down hierarchical ikta order "decreed" from the top. The dominions of the warlords were granted by the central authority for their military service to the "state", and the warlords were submissive to this centralized and hierarchical political order. This was not the case in Tarih II. Inspired by Köprülü and others, the economic structure was dubbed "feudalism" (or in the favorite phrase of Köprülü, "Turkish medieval feudalism") in which the relative powers of the centrifugal and central forces were determined by their relative military shrewdness, thus recognizing the permanent tension between the raiding commanders and their overlords (Deliorman 1988: 278). Although Tarih II also accentuated the unity of the Turks under the aegis of one single "civilization" and all-encompassing political, economic, and military structure, this unity and centralism was reconciled with the noble raider character of the Turcoman nomads marching across the frontiers. In contrast, in the Turco-Islamic imagination, this organicism was more explicit and any mischief among the Turks was regarded as subversion which could easily be abused and manipulated by the insidious foes of the Turks (Deliorman 1988: 279).

It is also remarkable that whereas Dirimtekin, a representative of the Kemalist paradigm, in 1936 accused Alp Aslan for making a devastating blunder in freeing the Roman emperor and criticized his narrow foresight in his analysis from the perspective of military science, (Dirimtekin 1936: 46) the proponents of Turco-Islamic synthesis praised his benevolence, magnanimity and for "showing mercy, moderation and humanitarianism" (Kafesoğlu 1956: 19) which they saw as Turkish and Islamic virtues. ${ }^{41}$ Differing attitudes toward Alp Arslan arguably stemmed from the fact that whereas for Dirimtekin it was the Seljukid military commanders and raiders that had epitomized Turkishness, for the proponents of Turco-Islamic synthesis Turkishness was embodied in the person of the sultan. Furthermore, whereas for Dirimtekin, who was enthralled with Prussian militaristic visions, it was the sheer might of the Turks that was to be esteemed, in the upcoming decades it was also the moral righteousness of Turks that had to be cherished and emphasized.

Nevertheless, what was common in both of the narratives was the obsession with "unity" and the aversion to any kind of schism within the imagined Turkish organic 
nation. The state was consecrated to maintain "unity" and avoid sedition among the Turks. Hence, the state was regarded as the fulcrum of the nation. The notion of kut [mandate] embedded in the Turkic political ideology (as we also observed in the Ottoman chroniclers), which grants a superior authority the mandate to rule over the steppes and the Turks, was also to be invoked to historicize this obsession with unity and extend the late Ottoman and republican traumas to the past.

Hence, since the idea of a politically divided Anatolia was subversive, its unity had to be secured. The nation was also imagined ahistorically and as an organic whole. Yet the nation was indefinable in the absence of a state. The Turkish nation was to be realized and defined via obedience to a political organization. This vision established the main contours and premises of the historical visions of the Seljuks of Rum posited within the larger Turkic history as a crucial stage in the continuum from Central Asia to the $20^{\text {th }}$ century Turkish republic. ${ }^{42}$

\section{Conclusion : The Failure of Studies of Seljuks of Rum in Turkey and the Waning of the Manzikert Myth}

Although the imagery of freestanding Turcomans raiding Anatolia (not unlike the imagery of the Germans of Tacitus raiding the effeminate Romans) and of a "Turkish Middle Ages" before the establishment of a centralized Ottoman state provided inspiration for the Turkist phase of Turkish nationalism by positing the Seljuks of Rum as the crucial link between contemporary Anatolian Turkishness and Central Asian Turkishness from time immemorial, this imagery was arguably marginalized with the étatisation of Turkish nationalism. Simultaneously, the abandonment of the dilettante romanticism of the 1930s allowed the development of a serious study of Ottoman history in line with Kemalist premises in the 1940s. The conscious neglect of Ottoman history in the radical republic of the 1930s gradually gave way to a historiography where Ottoman history emerged as the crux in the 1940s. The lack of knowledge of languages such as Chinese, Russian, and Sogdian meant that no academically serious study of Central Asian Turkic history could be undertaken. Similarly, Islamic Turkic history required a profound knowledge of Arabic and Persian, and a rigorous methodology. The presence of newly indexed archival documents and an affinity with the Ottomans rendered Ottoman history the only promising area of historical study for Turkish academia.

What is striking is that, after a stagnation in Seljuk studies, it emerged as a popular theme among conservative historians beginning in the 1960s. There were several reasons for this development. One was the relative familiarity of these conservative historians with the prerequisite languages (Arabic and Persian). The ideological reasons also should not be omitted. The ethos of the Islamic worldview, the Islamic ideology of conquest, and the affinities of the Seljuks with Turkic ecumenism via Manzikert animated these historians.

The study of the Seljuks of Rum was subsumed under the rubric of the studies of Islamic-Turkish states. It was depicted as a crucial phase of the pre-destined Turkish historical trajectory, being the indispensable intermediary sequence duringwhich Anatolia became the homeland for Turks. Nevertheless, it was not deemed as purely an Anatolian phenomenon but analyzed within the ecumenism of Turkishness and the 
abode of Islam with Manzikert functioning as the critical nexus between the two. It was no coincidence that the Turkish scholars who studied the Seljuks of Rum had also examined other Islamic-Turkic polities (rather than the Ottomans). Hence, the study of the Seljuks of Rum was subsumed under global Turkic history.

With the end of the Cold War, the ideology of the Turco-Islamic synthesis waned and became irrelevant as the anti-communist Cold War alliance between Islamism, Turkish nationalism and the center-right eroded. The Turkish anti-communist right's parochial visions were superseded by the new discourses promoted by new generations of Islamist, right-wing nationalists and conservatives who had very different visions from those of the Turkish right during the Cold War. The epic [gaza] narrative of Manzikert was superseded by new epics and myths. In the 1990s, especially after the municipality of Istanbul began to be governed by mayors from the Islamist parties, the theme of the 1453 "conquest of Istanbul" by Mehmed II emerged as the most celebrated historical event which Turkish rightists, Islamists, and right-wing nationalists subscribed to (Çınar 2005: 155-167). It seems that the capture of Istanbul is now regarded as a historical conjuncture more important than ever before. Meanwhile, the conquering, Turkification and Islamization of Anatolia lost the prestige it had enjoyed in previous decades. Manzikert's moment of glory passed with the end of the Cold War and lost its emotional power in the nationalist imagination.

This article has briefly overviewed the historiography and meanings attributed to the Battle of Manzikert and the Seljuks of Rum throughout the evolution of Turkish nationbuilding and nationalism. It has attempted to demonstrate how these imageries have been instrumentalized by competing visions of Turkishness and how they have been invented and reinvented since the late- $19^{\text {th }}$ century. However, the changing meanings attributed to the myth of Manzikert and the Seljuks of Rum also demonstrate the contingent relation between the present and the past. The historical reservoir of references were selectively consumed by the contesting nationally-minded intelligentsias. These themes gained prominence with the equation of the Turkish Heimat with Anatolia and were transformed in the different historicity of the Cold War. The historical reservoir or references did not determine the contours of modern national imaginations, but they did provide them with the necessary equipment and emotional fine-tuning.

\section{BIBLIOGRAPHIE}

Abdizade Hüseyin Hüsameddin (1329) Amasya Tarihi, Istanbul, Istikbal Matbaası.

Abdurrahman şeref (1315) Fezleke-i Tarih-i Devlet-i Osmaniye, Istanbul, Karabet Matbaası.

Ahmed Cevdet Paşa (1969) Kısas-ı Enbiya ve Tevarih-i Hulefa, Istanbul, Bedir Yayınları.

Ahmed Cevdet Paşa (1309) Tarih-i Cevdet, Dersaadet, Matbaa-1 Osmaniye.

Ahmed Midhat Efendi (1303) Mufassal Tarih-i Kurun-u Cedide, İstanbul, Kırk Anbar Matbaası. 
Ahmed Rasim (1326-1328) Osmanlı Tarihi, Istanbul, İkbal Kitabhanesi.

Ahmed Refik (1328) Tarih-i Umumi, Istanbul, Kitabhane-i İslam ve Askeri.

Ahmed Tevfik (1329) “Ankara'da Ahiler Hükümeti”, Tarih-i Osmani EncümeniMecmuası, vol. IV, no. 19, April.

Ahmed Vefik Paşa (1286) Fezleke-i Tarih-i Osmani, Istanbul, Amire Matbaası.

Akbayrak, Hasan (2009) Milletin Tarihinden Ulusun Tarihine, Istanbul: Kitabevi.

Akçuraoğlu Yusuf (ed.), (2009 [1928]) Türk Yıll, Ankara, Türk Tarih Kurumu.

Akdağ, Mustafa (1959) Türkiye'nin İktisadi ve İçtimai Tarihi(1243-1453), Ankara, Ankara Üniversitesi Dil ve Tarih-Coğrafya Fakültesi Yayınları.

Ali Kemali (1932) Erzincan, Istanbul, Resimli Ay Matbaası.

Ali Reşat (1929) Umumi Tarih: Lise Kitapları, 1. Sinıf, Istanbul, Devlet Matbaası.

Ali Seydi (1329) Devlet-i Osmaniye Tarihi, Dersaadet, Kanaat Matbaası.

Anderson, Benedict (1983) Imagined Communities, London-New York, Verso.

Alpayer, Refii, Özatalay, şinasi(1962), Mükrimin Halil Yinanç’tan Sohbetler, Istanbul, Yağmur Yayınları.

Alptekin, Coşkun (1971)Selçuklu Paraları, Ankara, Güven Matbaası.

Arık, M. Oluş (1971) Bitlis Yapılarında Selçuku Rönesansı, Ankara, Güven Matbaası, 1971.

Arnakis, G.G. (1953) "Futuwwa Traditions in the Ottoman Empire Akhis, Bektashi Dervishes, and Craftsmen", Journal of Near Eastern Studies, vol. 12, no. 4, October.

Aşık Paşazade (2003) Osmanoğullarının Tarihi, Istanbul: K Kitaplığı.

Aslanapa, Oktay et al. (19719Selçuklu Sanatı Bibliyoğrafyası, Istanbul, Yapı ve Kredi Bankası.

Avcıoğlu, Doğan (1983) Türklerin Tarihi, Istanbul: Tekin Yayınevi, 1983, v. V.

Aykut, A. Sait Aykut (2004) “Tancalı İbn Battuta ve Seyahatnamesi”; İbn Battuta Tanci, İbn Battuta Seyahatnamesi, Istanbul, Yapı Kredi YayınlarıVol. I.

Franz Babinger, "Der Islam in Kleainasien: Neue Wege der Islamforschung”, Zeitschrift der Deutschen Morganlandischen Gesellschaft, vol. LXXVI, 1922.

Babinger, Franz Babinger (1338) “Anadolu'da İslamiyet”, Darülfünun Edebiyat Fakültesi Mecmuast, vol. II, no. 3, July pp. 188-221.

Babinger, Franz; Köprülü, Fuad (2003) Anadolu'da İslamiyet, Istanbul: İnsan Yayınları Baha Said (2006) Türkiye'de Alevi-Bektaşi, Ahi ve Nusayri Zümreleri,Istanbul, Kitabevi. Berktay, Halil Berktay (1983a) “Tarih Çalışmaları”, in Cumhuriyet Dönemi Türkiye Ansiklopedisi, Istanbul, İletişim Yayınları.

Berktay, Halil (1983b) Cumhuriyet İdeolojisi ve Fuat Köprülü, Istanbul, Kaynak Yayınları.

Atalay, Besim (1339) Maraş Tarihi ve Coğrafyası,Istanbul, Matbaa-i Amire.

Bilgiç, Emin (1971a)Malazgirt Zaferi, Ankara, Selçuklu Tarih ve Medeniyet Enstitüsü.

Bilgiç, Emin (1971b) “Özel Sayı Hakkında”, Selçuklu Araştırmaları Dergisi, no. 3. 
Birgen, Muhittin (2006) Ittthat ve Terakki'de On Sene (Zeki Arıkan ed.), Vol. II, Istanbul, Kitap Yayınevi.

Confino, Alon (1997) The Nation as a Local Metaphor: Württemberg, Imperial Germany and National Memory, 1871-1918, Chapel Hill, University of North Carolina Press.

Cahen, Claude (1934)“La Campaine de Manzikert d'aprés les Sources Musulmanes”, Byzantion, vol. IX, no. 2.

Cahen, Claude (1968) Pre-Ottoman Turkey, New York, Taplinger Publishing Company.

Cahen, Claude (1986) EI, “Alp Arslan”, E.J. Brill, 1986, vol. I.

Cahen, Claude (1992) Türklerin Anadolu'ya İlk Girişi, Türk Tarih Kurumu Yayınları, 1992.

Cahun, Leon (1896) Introduction à l'histoire de l'Asie: Turcs et Mongols des origines à 1405, Paris.

Copeaux, Etienne (1997) Espaces et Temps de la Nation Turque, Paris, CNRS.

Copeaux, Etienne (2000) Les Prédécesseurs Médiévaux d'Atatürk: Bilge Kaghan et le Sultan Alp Aslan", Revue des Mondes Musulmans et de la Méditerranée, no. 89-90, July.

Çağatay, Neşet (1974) Bir Türk Kurumu Olan Ahilik, Ankara, Ankara Üniversitesi Basımevi.

Çelik, Hüseyin (1994) Ali Suavi ve Dönemi, Istanbul, İletişim Yayınları.

Çınar, Alev (2005) Modernity, Islam, and Secularism in Turkey, Minneapolis, London, University of Minnesota Press.

Danişmend, İsmail Hami (1971) İzahlı Osmanlı Tarihi Kronolojisi, Istanbul, Türkiye Yayınevi.

Deliorman, Altan (1998) Tarih I, n.p., Bayrak Basım/Yayım/Tanıtım.

Demirci, Nurdan (1995) Prof. Dr. Osman Turan'ın Hayatı ve Eserleri, Istanbul, Boğaziçi.

Deringil, Selim (1998) The Well-Protected Domains, London; New York, I.B. Tauris.

Dilaver, Sadi (1971) Anadolu'da Tek Kubbeli Selçuklu Mescitlerinin Mimarlık Tarihi Yönünden Önemi, Istanbul: İstanbul Üniversitesi Edebiyat Fakültes.

Dirimtekin, Feridun (1936) Malazgirt Meydan Muharebesi, n.p.

Dirimtekin, Feridun (1943) Malazgirt Meydan Muharebesi, Istanbul, Ahmet Halit Kitabevi.

Duby, George (1973) Le Dimanche de Bouvines, Paris, Gallimard.

Ersanlı, Büşra (2003) İktidar ve Tarih, Istanbul, İletişim Yayınları.

Erzi, Adnan Sadık (ed.) (1956) El Evamirü'l Ala'iyye fi'l Umuri'l Ala'iyye, Ankara, Türk Tarih Kurumu Yayınları.

Faik Sabri (1929) Türkiye Coğrafyası, Istanbul: Devlet Matbaası.

Galanti, Avram (1951) Ankara Tarihi, Istanbul: Tan Matbaası, 1951.

Georgeon, François (1996) Türk Milliyetçiliğinin Kökenleri: Yusuf Akçura, Istanbul, Tarih Vakfı Yurt Yayinları.

Gibbons, Herbert Adams (1916) The Foundation of the Ottoman Empire, Oxford: Clarendon Press Gordlevsky, Vladimir (1988) Anadolu Selçuklu Devleti, Ankara: Onur Yayınları

Gölpınarlı, Abdülbaki Gölpınarlı (1949-1950) “İslam ve Türk İllerinde Fütüvvet Teşkilatı”, İstanbul Üniversitesi İktisat Fakültesi Mecmuası, vol. XI 
Green, Abigail (2001) Fatherlands: State-Building and Nationhood in Nineteenth Century Germany, Cambridge; New York: Cambridge University Press

Gülekli, Nurettin Can (1948) Ankara: Tarih-Arkeoloji, Ankara: Doğuş Matbaası

Gürpınar, Doğan (2004) The Seljuks of Rum in the Turkish Republican Nationalist Historiography, unpublished MA thesis, Sabanc1 University

Güvenç, Bozkurt şaylan, Gencay, Tekeli, İlhan, Turan, şerafettin (1994) Türk-İslam Sentezi, Istanbul: Sarmal Yayınevi

Halil Edhem (1332) “Ankara Ahilerine Aid İki Kitabe”, Tarih-i Osmani EncümeniMecmuası vol. VII, no. 41 , December

Halide Edib (1329) Yeni Turan, İstanbul: Tanin Matbaası

Hillenbrand, Carole (2007) Turkish Myth and Muslim Symbol: The Battle of Manzikert, Edinburgh: Edinburgh University Press

Hobsbawm, Eric J. (1990) Nations and Nationalism Since 1780, Cambridge: Cambridge University Press

Hroch, Miroslav (1985) Social Preconditions of National Revival in Europe, New York: Cambridge University Press

İbn Battuta (1290) Tercüme-i Seyahatname-i İbn Batuta, Istanbul: Süleyman Efendi Matbaası

İbn Battuta (1328) İbn Battuta Seyahatnamesi, Istanbul: Matbaa-i Amire

İbn Battuta Tanci (2004) İbn Battuta Seyahatnamesi, İstanbul: Yapı Kredi Yayınları

Ibn-i Kemal (1970) Tevarih-i Al-i Osman, I. Defter, Ankara: Türk Tarih Kurumu Basımevi

İğdemir, Uluğ (1973) Cumhuriyetin 50. Yılında Türk Tarih Kurumu, Ankara: Türk Tarih Kurumu Yayınları

İsmail Galib (1309) Takvim-i Meskukat-ı Selçukiye, Konstantiniyye: Mihran Matbaası

Kafadar, Cemal (1995) Between Two Worlds, Berkeley: University of California Press

Kafadar, Cemal (2007) "A Rome of One's Own: Reflections on Cultural Geography and Identity in the Lands of Rum", Muqarnas, v. 24

Kafesoğlu, İbrahim (1955) “Selçuklu Tarihinin Meseleleri”, Belleten, v. XIX, no.76, October

Kafesoğlu, İbrahim (1956) Malazgird Meydan Muharebesi, İstanbul: Maarif Matbaası

Kafesoğlu, İbrahim (1956) "Selçuklu Tarihi Meselelerine Toplu bir Bakış”, Belleten, v. XXX, no: 119, July

Kafesoğlu, İbrahim (1966) Türk Milliyetçiliğinin Meseleleri, Ankara: Türk Kültürünü Araştırma Enstitüsü

Kafesoğlu, İbrahim (1972) Selçuklu Tarihi, Ankara: Milli Eğitim Basımevi

Kafesoğlu, İbrahim, Deliorman, Altan (1977) Tarih-Lise II, Istanbul: Milli Eğitim Basımevi

Kansu, Şevket Aziz (1943) “Selçuk Türkleri Hakkında Antropolojik İlk Bir Tetkik ve Neticeleri”, İkinci Türk Tarih Kongresi, Istanbul: Kenan Matbaası

Karaosmanoğlu, Yakup Kadri (2000) Gençlik ve Edebiyat Hatıraları, İletişim Yayınları

Katip Ferdi [Ali Emiri] (1331) Mardin Mülûk-i Artukiyye Tarihi, Istanbul: Kader Matbaası 
Kayalı, Kurtuluş (2000) “Mustafa Akdağ’ın Tarihçiliği Üzerine”, in Türk Düşünce Dünyasının Bunalımı, Istanbul: İletişim Yayınları, pp. 75-93

Konyalı, İbrahim Hakkı (1945) Nasreddin Hoca'nın şehri, Aksaray, Istanbul: Numune Matbaası Konyalı, İbrahim Hakkı (1946) Alanya=Alaiyye, Istanbul: Ayaydın Matbaası

Koshar, Rudy (1998) Germany's Transient Pasts: Preservation and National Memory in the Twentieth Century, Chapell Hill: University of North Carolina Press

Koşay, Hamit (1932) Ankara Budun Bilgisi, Ankara: Ulus Matbaası

Köprülüzade Mehmed Fuad (1328) “şinasi'nin şiirleri”, Servet-i Fünun, no. 25

Köprülüzade Mehmed Fuad (1329a) “şeyh Galip hakkında”, Servet-i Fünun, no. 63

Köprülüzade Mehmed Fuad (1329b) “Türk Edebiyatı Tarihinde Usül”, Bilgi Mecmuası, vol. I

Köprülüzade Mehmed Fuad (1329c) “Yeni Bir İlim:Halkiyat”, İkdam, 24 İkincikanun 1329c

Köprülüzade Mehmed Fuad (1329d) "Yunus Emre”, Türk Yurdu, vol. V

Fuad Köprülü, “Hoca Ahmed Yesevi”, “Çağatay ve Osmanlı edebiyatları üzerinde tesiri”, Bilgi Mecmuası, vol. I 1330.

Köprülüzade Mehmed Fuad (1331) “Selçukiler Devrinde Anadolu'da Türk Medeniyeti”, Milli Tetebbüler Mecmuası, no. 2

Köprülüzade Mehmed Fuad (1331) “Selçukiler Devrinde Anadolu'da Türk Medeniyeti”, Milli Tetebbüler Mecmuası, no. 2.

Köprülüzade Mehmed Fuad (1918) Türk Edebiyatında İlk Mutasavvıflar, Istanbul: Matba-1 Amire.

Köprülüzade Mehmed Fuad (1338-1339) “Anadolu'da İslamiyet: Türk İstilasından Sonra Anadolu Tarih-i Dinisine Bir Nazar ve Bu Tarihin Menbaları”, Darülfünun Edebiyat Fakültesi Mecmuası, . vol. II, no. 4, September 1338, pp. 281-311; vol. II, no. 5, November 1338; pp. 386-420; vol. II, no. 6 , January 1339, pp. 457-486.

Köprülüzade Mehmed Fuad (1931), Bizans Müesseselerinin Osmanlı Müesseselerine Te'siri, Istanbul, Evkaf Matbaası.

Köprülü, Fuad (1943) “Anadolu Selçuklu Tarihinin Yerel Kaynakları”, Belleten, vol. VII, no. 27.

Köprülü, Fuad (1976) Türk Edebiyatında İlk Mutasavvıflar, Ankara, Diyanet İşleri Başkanlığı Yayınları.

Köprülü, Fuad (1983) İslam ve Türk Hukuk Tarihi Araştırmaları ve Vakıf Müessesesi, Istanbul, Ötüken Yayınevi.

Köprülü, Fuad (1986) Edebiyat Araştırmaları, Ankara: Türk Tarih Kurumu Basımevi

Köprülü, Fuad (1986) “Türk Edebiyatı Tarihinde Usül”, in Edebiyat Araștırmaları, Ankara, Türk Tarih Kurumu Yayınları.

Köprülü, Fuad (1993) TheSeljuks of Anatolia, trans. Gary Leiser, Salt Lake City, University of Utah Press.

Köymen, Mehmet Altan (1947) Büyük Selçuklu İmparatorluğu Tarihinde Oğuz İstilası, Ankara, Türk Tarih Kurumu Yayınları.

Köymen, Mehmet Altan (1962) Anadolu'nun Fethi, Ankara, Türk Tarih Kurumu Yayınları.

Köymen, Mehmet Altan (1976) Tuğrul Bey ve Zamanı, Ankara, Kültür Bakanlığı-Kültür Serisi. 
Köymen, Mehmet Altan (1989) Büyük Selçuklu İmparatorluğu Tarihi, Ankara, Türk Tarih Kurumu Yayınları.

Köymen, Mehmet Altan (1992) Büyük Selçuklu Tarihi, v. III (Alp Arslan ve Zamanı), Ankara, Türk Tarih Kurumu Basımevi.

Kushner, David (1977) The Rise of Turkish Nationalism, 1876-1908, London, Totowa, Cass.

Lebovics, Herman (1994) True France, Ithaca; London, Cornell University Press.

Leiser, Gary (1988) A History of Seljuks, Ibrahim Kafesoğlu's Interpretation and the Resulting Controversy, Carbondale, Southern Illinois University Press.

Leiser, Gary (1993) "Introduction" in Fuad Köprülü, Islam in Anatolia after the Turkish Invasion, trans. Gary Leiser, Salt Lake City: Utah University Press.

Mayakon, İsmail Müştak (1940) Yıldız'da Neler Gördüm? Istanbul : Semih Lütfi Kitabevi.

Mellor, Ronald (1994) Tacitus, London: Routledge.

Mellor, Ronald (1999) The Roman Historians, London: Routledge.

Meskukatçı Ali (1340/1924) “Candaroğulları”, Türk Tarih Encümeni Mecmuası, vol. XIV, no. 1, February.

Müfide Ferit (2002) Aydemir, Istanbul, Kaknüs Yayınları.

Necib Asım (1316) Türk Tarihi, Istanbul,Dar-ül Tıbbıye-i Amire.

Necib Asım (1335) Türklerin Tarihi, Istanbul, Matbaa-ı Orhaniye.

Necib Asım, Mehmed Arif, (1340) Osmanl Tarihi, Istanbul, Tarih-i Osmani Encümeni.

Neşri (1949) Kitab-ı Cihan-Nüma, Ankara, Türk Tarih Kurumu Basımevi.

Christoph K. Neumann (1994) Das Indirekte Argument: Die Geschictliche Bedeutung Ahmed Cevdet Pashas Tar'ih, Münster, Hamburg, Lit Verlag.

Oktay, Emin (1951) Tarih (Orta Çağ), Istanbul, Remzi Kitabevi, 1951.

Oruç Bey (2007) Oruç Beğ Tarihi, Istanbul, Çamlıca.

Önen, Nizam (2005) İki Turan, Istanbul, İletişim Yayınları.

Özbaran, Salih (2004) Bir Osmanlı Kimliği: 14.-17.Yüzyıllarda Rum/Rumi Aidiyet ve İmgeleri, Istanbul, Kitap Yayınları, 2004.

Özkan, Hande (2002) TheHistory of Geographical Perceptions in the Turkish Republic, unpublished MA thesis, Boğaziçi University.

Öztürkmen, Arzu (1998) Türkiye'de Folklor ve Milliyetçilik, Istanbul, İletişim Yayınları.

Özyürek, Esra Özyürek (ed.) (2006) ThePolitics of Public Memory in Turkey, Syracuse, Syracuse University Press.

Palabıyık, Hanefi (2005) Ord. Prof. Dr. M.Fuad Köprülü’nün İlmi Hayatı ve Tarihçiliği, Ankara: Akçağ.

Park, George T. (1975) The Life and Writings of Mehmet Fuat Köprülü, unpublished dissertation, Johns Hopkins University.

Selçuklu Tarihi, Alpaslan ve Malazgirt Bibliyografyası (1971) Ankara, Milli Eğitim Basımevi.

Sevim, Ali Sevim (1972) "Malazgirt Meydan Savaşı ve Sonuçları”, in Malazgirt Armağanı, Ankara, Türk Tarih Kurumu Basımevi. 
Sevim, Ali Sevim (1988) Anadolu'nun Fethi, Ankara, Türk Tarih Kurumu.

Sevim, Ali (1990) Ünlü Selçuklu Komutanları, Ankara, Türk Tarih Kurumu Yayınları.

Sevim, Ali, Merçil, Erdoğan (1995) Selçuklu Devletleri Tarihi, Ankara, Türk Tarih Kurumu.

Sevim, Ali, Sümer, Faruk (1988) İslam Kaynaklarına Göre Malazgirt Savaşı, Ankara, Türk Tarih

Kurumu Yayınları.

Smith, Anthony D. (1986) The Ethnic Origins of Nations, Oxford, B. Blackwell.

Smith, Anthony D. (1991) National Identity, London, Penguin.

Smith, Anthony D. (1999) Myths and Memories of the Nation, New York, Oxford University Press.

Smith, Anthony D. (2003) Chosen Peoples, Oxford; New York, Oxford University Press.

Smith, Anthony D. (2009) Ethno-Symbolism and Nationalism, London; New York, Routledge.

Suny, Ronald Grigor Kennedy, Michael D. Kennedy (ed.) (2001) Intellectuals and the Articulation of the Nation, Ann Arbor, The University of Michigan Press.

Sümer, Faruk (1975) “Malazgird Savaşı'na Katılan Türk Beyleri”, Selçuklu Araştırmaları Dergisi, no. 4.

Malazgirt Zaferi ve Alp Arslan, Istanbul: Devlet Kitapları, 1968.

Şapolyo, Enver Behnan (1944) Kemal Atatürk ve Milli Mucadele Tarihi, Ankara, Berkalp Kitabevi.

şemseddin Sami (1307) Kamus-ul A'lam, “Anadolu”, Istanbul, Mihran Matbaası, vol. I.

Taeschner, Franz (1986) Encylopedia of Islam, “Anatolia”, Leiden, E.J. Brill, vol. I.

Tanpınar, Ahmet Hamdi (1995) Yahya Kemal, Istanbul, Dergah Yayınları.

Tansel, Fevziye Abdullah (1976) “Önsöz”, in Fuad Köprülü, Türk Edebiyatında İlk Mutasavvıflar, Ankara: Diyanet İşleri Bașkanlığı Yayınları.

Tarus, ílhan (1947) Ahiler, Ankara: Ulus Matbaası.

Taşkın, Yüksel (2007) Milliyetçi Muhafazakar Entelijansiya, İstanbul, İletișim Yayınları.

Thiesse, Anne-Marie (2007) “The Formation of National Identities”, Marion Demossier (ed.), The European Puzzle, New York, Berghahn.

Thiesse, Anne-Marie (2001) La Création des Identités Nationales, Paris, Seuil.

Thom, Martin (1995) Republics, Nations and Tribes, London, Verso.

T.T.T. Cemiyeti (1933) Tarih II, Ankara, Devlet Matbaası.

Tunçay, Mete (1999) Türkiye Cumhuriyeti'nde Tek-Parti Yönetiminin Kurulmast (1923-1931), Istanbul, Tarih Vakfı Yurt Yayınları.

Turan, Osman (1948a) “Celaledin Karatay, Vakıfları ve Vakfıyeleri”, Belleten, v. XII, no: 45, January.

Turan, Osman (1948b) Türkiye Selçuklularında Toprak Hukuku, Miri Topraklar ve Hususi Mülkiyet şekilleri”, Belleten, vol. XII, no. 47, July 1948b.

Turan, Osman (1948c) Gafletten Uyanalım! Universitedeki Solcu Hocalar Meselesi, Ankara, Doğuş Matbaası, 1948.

Turan, Osman (1952) “Selçuk Türkiyesi’nde Faizle Para İkrazına Dair Hukuki bir Vesika”, Belleten, vol. XVI, no. 62, April. 
Turan, Osman (1964) Türkiye'de Manevi Buhran: Din ve Laiklik, Ankara, şark Matbaası.

Turan, Osman (1969a) Selçuklular Tarihi ve Türk-İslam Medeniyeti, Istanbul, Turan Neşriyat Yurdu.

Turan, Osman (1969b) Türkiye'de Siyasi Buhran'in Kaynakları, Istanbul, Turan Neşriyat Yurdu.

Turan, Osman (1969c)Türk Cihan Hakimiyeti Mefkûresi Tarihi: Türk Dünya Nizamının Millî, İslâmî ve İnsanî Esasları, Istanbul, Istanbul Matbaası, 1969c.

Turan, Osman (1970) "Anatolia in the Period of the Seljuks and the Beyliks", in Bernard Lewis, P.M. Holt, Ann K.S. Lambton (ed.), TheCambridge History of Islam, Cambridge, Cambridge University Press.

Turan, Osman (1971) Selçuklular Zamanında Türkiye, Istanbul, Turan Neşriyat Yurdu.

Turan, Osman (1973) Türkler Anadolu'da, Istanbul, Hareket Yayınları, 1973.

Turan, Osman (1988) Türkiye Selçukluları Hakkında Resmi Vesikalar: Metin, Tercüme ve Araştırmalar, Ankara, Atatürk Kültür, Dil ve Tarih Yüksek Kurumu.

Türk Tarihinin Ana Hatları, Istanbul, Kaynak Yayınları, 1996.

Uluçay, Çağatay, Gökçen, İbrahim (1939) Manisa Tarihine Genel Bir Bakış, Istanbul, Resimli Ay Matbaası.

Uzunçarşılıŏlu İsmail Hakkı (1927) Tokat, Niksar, Zile, Turhal, Pazar, Amasya Vilâyet, Kaza ve Nahiye Merkezlerindeki Kitabeler, Istanbul, Milli Matbaa.

Uzunçarşılıŏlu İsmail Hakkı (1929) Afyon Karahisar, Sandıklı, Bolvadin, Çay, İsaklı, Manisa, Birgi, Muğla, Milas, Peçin, Denizli, Isparta, Atabey, ve Eğirdir'deki Kitabeler ve Sahip, Saruhan, Aydın, Menteşe, İnanç, Hamit Oğulları Hakkında Malûmat, Istanbul, Devlet Matbaası.

Uzunçarşılığlu İsmail Hakkı (1932)Bizans ve Selçukiylerle Germiyan ve Osman Oğulları Zamanında Kütahya şehri, Istanbul, Devlet Matbaası.

Uzunçarşılı, İsmail Hakkı (1937) Karamanoğlu İbrahim Bey Vakfiyesi, Istanbul, Devlet Matbaası.

Uzunçarşılı, İsmail Hakkı (1941) Osmanlı Devleti Teşkilâtına Medhal : Büyük Selçukiler, Anadolu Selçukileri, Anadolu Beylikleri, illhâniler, Karakoyunlu ve Akkoyunlularla Memlûklerdeki Devlet Teşkilâtına Bir Bakış, Istanbul, Maarif Matbaası.

Uzunçarşıll, İsmail Hakkı (1943) “On Dört ve On Beşinci Asırlarda Anadolu Beyliklerinde Toprak ve Halk İdaresi", İkinci Türk Tarih Kongresi, Istanbul, Kenan Matbaası.

Uzunçarşılı, İsmail Hakkı (1945) Osmanlı Devletinin Saray Teşkilatı, Ankara, Türk Tarih Kurumu Yayınları.

Uzunçarşılı, İsmail Hakkı $(1937,1969)$ Anadolu Beylikleri ve Akkayunlu, Karakoyunlu Devletleri, Ankara, Türk Tarih Kurumu Yayınları, Ankara.

Ülken,Hilmi Ziya (1961) “Kaybettiğimiz Büyük İlim Adamı: Mükrimin Halil Yinanç”, Hür Vatan, 26 December.

Üstel, Füsun (1993) “Türk Milliyetçiliğinde Anadolu Metaforu”, Tarih ve Toplum, no: 109, January.

Vryonis, Speros (1971) The Decline of Medieval Hellenism in Asia Minor, Berkeley, University of California Press.

Vryonis, Speros (1981) Byzantium, Seljuks and Ottomans, Malibu, Undena Publications.

Williamson, George S. (2004) The Longing for Myth in Germany: Religion and Aesthetic Culture From Romanticism to Nietzsche, Chicago, The University of Chicago Press. 
Wittek, Paul (1934) Das Fürstentum Mentesche: Studie zur Geschichte Westkleainasiens im 13-15. Jh, Istanbul, Universum Druckerei.

Yinanç, Mükrimin Halil (1340) “Feridun Bey Münşeatı”, Türk Tarihi Encümeni Mecmuası, vol. XIV, no. 4, July.

Yinanç, Mükrimin Halil (1944) Türkiye Tarihi: Selçukiler Devri, Istanbul, Burhaneddin Matbaası.

\section{NOTES}

1. For Ahmed Cevdet Pasha, his historical writings and the political and ideological concerns he expressed in his historical output, see Neumann 1994.

2. Curiosity towards pre-Islamic Turkic history was prevalent as early as the 1860s (Çelik 1994: 621-622). Necib Asım, the pioneering Turkist of the Hamidian era, also suggested that Sumerians and Akkadians were Turks "who established the foundations of Babylonian civilization" (Necib Asim 1335:11). Nevertheless, he was not the first one to claim that Sumerians were Turks. Ziya Gökalp and Hüseyin Hüsameddin had previously made the same claim. See Abdizade Hüseyin Hüsameddin 1329. The Turanian origins of the Mesopotamian civilizations were first articulated by Hungarian scholars in the first half of the $19^{\text {th }}$ century and by Western scholars beginning in the 1870s, and were then imported by Turkish intellectuals (Önen 2005: 43).

3. Although the term "Turkish nationalists" could also be used, "Turkist" seems more appropriate to demarcate those who entertained an exclusively ethnic sensitivity and were interested in the pre-Islamic (as well as Islamic) ancient Turkic culture from those who espoused a certain idea of nationhood without necessarily glorifying Turkic ancestry and emphasized a common Muslim bond and a porous political identity built around the Ottoman state.

4. For a comprehensive account of Köprülü's intellectual biography, see Park 1975.

5. For a review of the emergence and development of the scholarship on the Seljuks of Rum from the 1910s to 1930, see Gordlevksy 1988: 11-36. For the state of the study of Turcoman principalities, see Wittek 1934: vii-xi. Also for a discussion of the emergence of the first scholarly interest in the "rise of the Ottoman state" in the late-13th- and early-14th-century Bithynia in Western Anatolia, see Kafadar 1995: 9-12, 29-44; Berktay 1983b: 17-20; Babinger, Köprülü 2003: 13.

6. For its reprint in the Latin alphabet, see Köprülü 1986: 3-47.

7. Baha Said studied and praised the Anatolian heretical sects, Bektashis and Alevis in the 1910s, depicting them as manifestations of Turkish Islam in opposition to foreign-imposed Sunnah Islam. For the collection of his articles, see Baha Said 2006.

8. For some vivid narratives of this interpretation of Islam, see Fuad Köprülü (1976:251-253; 349-357).

9. For example see the novels of Halide Edib and Müfide Tek (Halide Edib 1329; Müfide Ferit 2002 [1918]).

10. (Babinger 1338: 188-221). For the Latin transcription of its Turkish translation, see Babinger and Köprülü (2003: 11-37).

11. For the text, see Babinger and Köprülü 2003: 41-122. For the English translation of Köprülü's article, see Köprülü 1993.

12. Originally published in Belleten 1938 with the French title "Les Institutions Juridiques Turques au Moyen Age”. For the Turkish version of the article, see Köprülü (1983: 3-35).

13. Also see Köprülüzade Mehmed Fuad 1931: 20-25.

14. Turan is a term that refers to the mythical and ancestral Turkic land and simultaneously implies the future unity of Turks (and other Turanic races such as Hungarians). It is in fact taken from Iranian mythology (Önen 2005).

15. For the full list of the articles that appeared in the journal, see Akbayrak 2009: 475-507. 
16. For the articles and publication policies of the local People's Houses journals, see Öztürkmen 1998: 116-120.

17. The interest in the local history in early 20th-century France also did not challenge the national narrative but on the contrary supported and reinforced the national narrative. See Lebovics 1994: 137, Koshar 1998; Confino 1997.

18. Most of the late Ottoman textbooks simply called the polity Selçuklular, abstaining from defining it with reference to its geography. Ahmed Refik, in his monumental Tarih-i Umumi, named the polity Rum Selçukluları (Ahmed Refik 1328: v. VI, 286). Also see Necib Asım, Mehmed Arif 1340: v. I, 441; Ahmed Cevdet Paşa 1309, v. I; Necib Asım 1316.

19. For the interesting geographical, ethnic and cultural meanings and attributes of the conceptRum, see Kafadar 1994: 7-25; Özbaran 2004.

20. Köprülüzade Mehmed Fuad, “Anadolu'da İslamiyet: Türk İstilasından Sonra Anadolu Tarih-i Dinisine Bir Nazar ve Bu Tarihin Menbaları”, Darülfünun Edebiyat Fakültesi Mecmuası, . vol. II, no. 4, September 1338, pp. 281-311; vol. II, no. 5, November 1338; pp. 386-420; vol. II, no. 6, January 1339, pp. 457-486.

21. Paul Wittek's monograph on the principality of Menteşe (Wittek 1934) had appeared in 1934 and was translated to Turkish in 1944.

22. For a review of the academic output on the Akhis in the first decades of the $20^{\text {th }}$ century, see Arnakis 1953.

23. For a classical study on the Turkification and Islamization of Anatolia, see Vryonis 1971; Vryonis 1981.

24. Even in 1928, in the yearbook of the Turkish Hearths, the Battle of Manzikert was only briefly mentioned as an event which took place "exactly nine and a half centuries before the last assault of the Greeks on Anatolia", but no name was attributed to the battle (Akçuraoğlu Yusuf 2009: 42).

25. Feridun Dirimtekin, Malazgirt Meydan Muharebesi, 1936, p. 48. A second edition of the study was published by Ahmet Halit Publishing House seven years later (Dirimtekin 1943).

26. For an analysis of Turco-Islamic synthesis, see Taşkın 2007.

27. For the "Turco-Islamic synthesis" see Taşkın 2007 ; Güvenç, şaylan, Tekeli, Turan 1994. Also see Kafesoğlu's Turco-Islamic manifesto (Kafesoğlu 1966).

28. (Turan 1970 : 231-262 ; Turan 1969; Turan 1971; Turan 1988; Turan 1948a; Turan 1948b ; Turan 1952; Turan 1973). Besides his scholarly work on Seljuks and medieval Turkic history, Turan also authored numerous volumes where he articulated his political views and assailed leftists and "Westerners" whom he accused of being alienated from Turkishness and its spiritual base (Turan 1948c; Turan 1964; Turan 1969b).

29. For the rise of the "myth of Manzikert" in the 1970s, also see Hillenbrand 2007: 203-219.

30. For example, see Turan 1969: 142-144.

31. For an insightful comparative perspective for Manzikert, see George Duby's monumental study of the construction of the myth of the Battle of Bouvines in Capetian France (Duby 1973).

32. For some studies of Manzikert conducted by historians affiliated with the Turco-Islamist school, see Sevim and Sümer 1988; Sümer 1975: 197-207; Sevim 1990; Sevim 1972: 219-229; Selçuklu Araştırmalaraı Dergisi-Malazgirt Özel Sayısı 1972.

33. For the association between Atatürk and the other members of the medieval Turkic pantheon, see Copeaux $2000: 217-243$.

34. For a critical study of the scholarship conducted by the proponents of the Turco-Islamic school, see Gürpinar 2004: 68-108.

35. For the mechanisms of "forgetting" in the construction of Turkish national imagination, see Özyürek 2006.

36. For the consolidation of state power in Turkey by the early 1930s see Tunçay 1999.

37. For the replacement of the Kemalist course books with the pro-Western and "humanist" textbooks, see Copeaux 1997: 107-108. 
38. Also see Sevim 1990.

39. "[Alp Arslan] Türkmen beylerine bütün Anadolu'nun zabtını emretti."

40. For the transformation of German nationalism in the $19^{\text {th }}$ century, see Williamson (2004); Green (2001); for the assessment of this process as a continent-wide phenomenon, see Thom (1995).

41. For depiction and praising of Alp Arslan's magnanimity towards Romanos Diogenes, see Turan (1971 29-32) ; Turan (1969 : 140-142) ; Sevim (1988 : 88-91).

42. The interpretations of the Seljuks of Rum by Mustafa Akdağ and Doğan Avcioğlu contrast with the interpretations of conservative historians and also merit a brief treatment, although they need to be assessed more throughly elsewhere. Mustafa Akdağ (1913-1973), a prominent economic historian and politically a left-leaning Kemalist, pursued a neo-Köprülüan approach in his historical methodology, but rather than documenting a medieval feudalism, Akdağ sought to demonstrate the prominence of cities and urban economy in Seljukid Anatolia (Akdağ 1959; Kayalı 2000: 75-93). Doğan Avcıoğlu (1926-1983) who was not a professional historian but a "professional revolutionary" after his disillusionment with (socialist) politics, devoted himself to the "scientific" study of Turkic history in the second half of the 1970s. He adapted Marxian historical analyses, and more importantly Engels' The Origin of the Family, Private Property and the State, to Turkic history. Although his meticulous opus was a major contribution, he romanticized the age of Seljuks of Rum and the centrifugal forces allegedly resisting against the central forces under disguise of "scientific" Marxism, not unlike Engels' romanticization of Germans influenced by Tacitus' Germania. Whereas, as argued in this study, the Kemalist passion for freedom-loving nomadic warriorism had been abandoned in favor of the image of strong and efficient state, the leftist-Kemalist Avcioğlu attributed socialist overtones to the alleged egalitarianism of preOttoman Anatolian nomads. He was also highly influenced by Fuad Köprülü, whom he merged with Friedrich Engels in accordance with his merging of socialist convictions with Kemalist premises (Avcioğlu 1983, v. I). For Tacitus and his impact on $19^{\text {th- }}$ century historiography in general and Engels in particular see Mellor (1994); Mellor (1999: 76-109).

\section{RÉSUMÉS}

This article discusses the historiography of the Seljuks of Rum as it emerged in the early $20^{\text {th }}$ century and developed in the Republican Era, and how the Seljuks of Rum were viewed within different national imaginations, thus providing an arsenal of arguments for contesting claims over Turkic history. Rather than discussing the development of the historiography of the Seljuks of Rum as an academic discipline, the article scrutinizes what meanings and symbolisms were attributed to the Seljuks of Rum at different historical moments by different actors. The article also examines the portrayal of the Battle of Manzikert and its refashioning as one of the constitutive moments of Turkic history in the 1970s.

\section{INDEX}

Keywords : Manzikert (battle), Rum, Seljuks, Turkey 